\title{
It's a wonderful hypogean life: a guide to the troglomorphic fishes of the world
}

\author{
Aldemaro Romero \& Kelly M. Paulson \\ Environmental Studies Program and Department of Biology, Macalester College, 1600 Grand Ave., St. Paul, \\ MN 55105-1899, U.S.A. (e-mail: romero@macalester.edu)
}

Received 15 February $2001 \quad$ Accepted 1 March 2001

Key words: hypogean fishes, biodiversity, systematics, taxonomy, geographical distribution, convergent evolution

\section{Synopsis}

There are at least 86 species of troglomorphic fishes belonging to 18 families. Some of those families are characterized by features that can be labeled as preadaptations to the hypogean life; others are not. The level of structural reduction in eye development and pigmentation is highly variable, even within some populations. Reduction in number and complexity of scales does occur but has yet to be fully documented. Reduction in the size and structure of the swim(gas)bladder may be another troglomorphic feature. There is considerable doubt on the taxonomic position of many species of troglomorphic fishes given that a number of them have been described solely on the basis of morphology while genetically they may be very closely correlated to genera different from those they have been assigned to. Geographically speaking there are no evident patterns since many of those species are not found in karstic areas but in phreatic waters. These fishes represent an excellent example of convergent evolution.

\section{Introduction}

The rate of discovery of new species/populations of troglomorphic fishes continues to increase rapidly. Although a list of these fishes has been published recently (Weber 2000), since Thinès (1969) there has been no comprehensive attempt to summarize the most important information about them. This paper aims to fill that gap and to serve as a general reference for this volume. We have not included non-troglomorphic fishes found in caves for this account because they have been summarized elsewhere in the volume (Poly 2001). At least one species, Varicorhinus (Scaphestes) macrolepis, hibernates for six months in caves (Zhang 1986). Also, we are aware that a number of troglomorphic species have been reported but not formally described (e.g., Trajano 1997c) and others seem to show only a few signs of troglomorphism (e.g., Burr et al. 2001). However, for the sake of simplicity, we decided to stick with those whose taxonomic status and troglomorphism has been clearly established.

\section{Methods}

We collected all available information on troglomorphic fishes published up to January 2001 following the methodology described in Romero (2001). The species were grouped by family following Nelson's (1994) systematic order. For each family a general summary of their biology is given to indicate whether or not they present generalized characters that could be understood as preadaptations to hypogean life, e.g., nocturnal habits or sensory systems that enhance informationgathering in dark waters. Some remarks are also made about the proportion of species known in comparison to how many of them are troglomorphic.

Given that for most genera and species their phylogenetic relationships with the rest of the family is uncertain, genera within families, as well as species within genera, were listed alphabetically. The species were numbered in order to facilitate the reading of the maps (Figures 1, 2). Unless otherwise indicated, the information for each species comes from the 


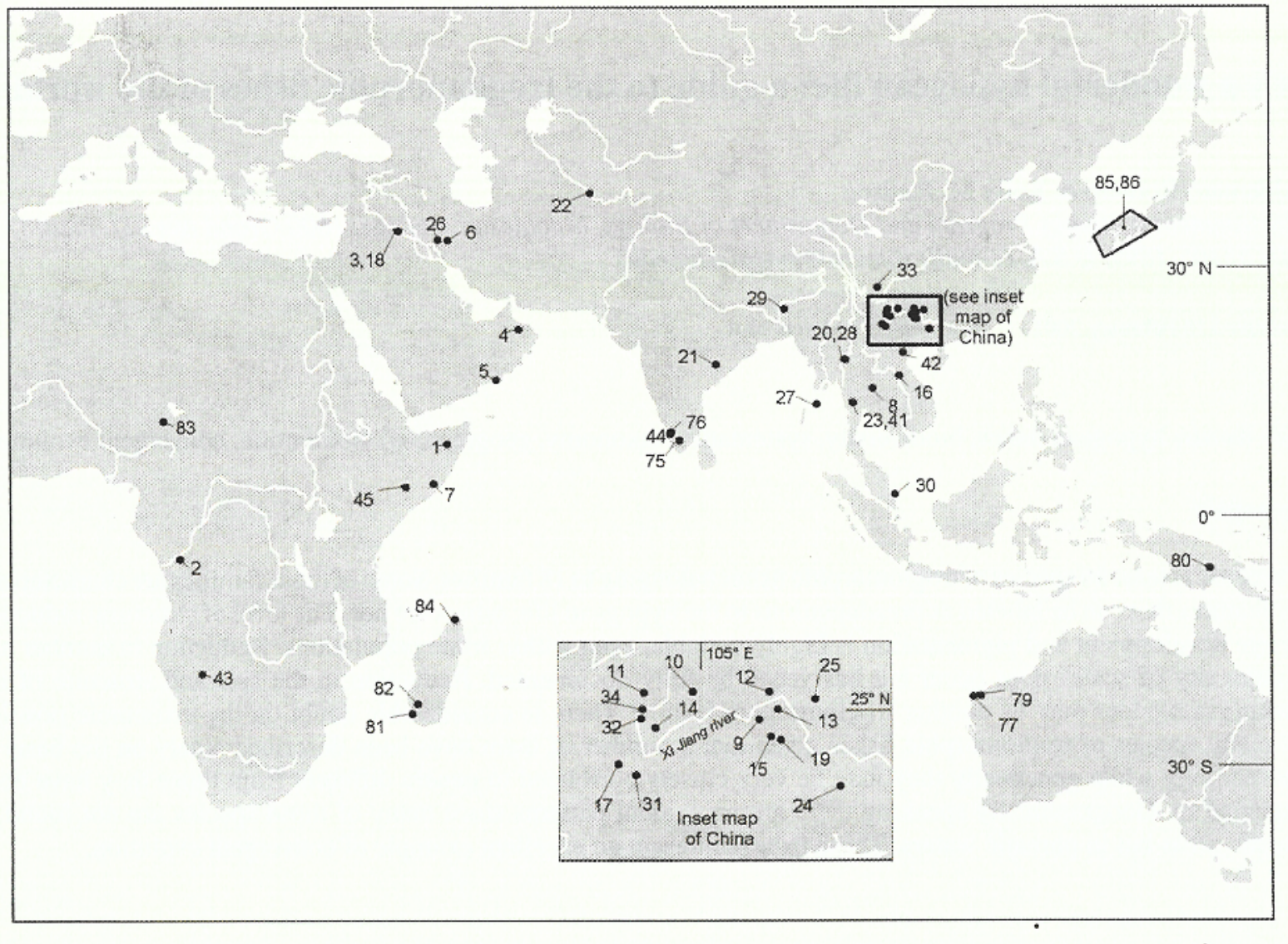

Figure 1. Localities and distributional areas for troglomorphic fishes in the Old World. Numbers represent species as cited in the text.

original description. Common name(s) are given if known. Etymology is given only for those names that were created to identify the hypogean/troglomorphic species/populations. Style for referring to etymologies follows Brown (1956) and Gotch (1995). Major synonyms are given only if they represent or have represented a source of confusion. Historical information is provided only if available. The remarks section aims to summarize information about troglomorphic features (reduction in eyes, pigmentation, and scales), behavioral features and phylogenetic relationships. Information on their conservation status is not included since it is summarized elsewhere in this volume (Proudlove 2001).

The maps accompanying this article (Figures 1,2) were created using Arc View software in the Macalester College Cartography Laboratory in January 2001. The maps are projected with the Mercator projection, which does create some distortion in the area of landmasses towards the poles, but since these maps exclude much of the polar landmasses and that troglomorphic fishes are not found at high latitudes, this is not much of an issue. Latitudes and longitudes of troglomorphic fish distributions were determined using one of several methods: sometimes latitude and longitude information was found in the article describing the species; sometimes a description of the location was given (with varying degrees of accuracy and reproducibility), and latitude and longitude were determined using atlases and other sources; other times a range was given (as in the southeastern US and in Japan), and the best attempt was made to draw a polygon encompassing these regions; finally, some articles gave no more than a sketchy description of the location (as with some of the fishes from China) and difficulties in translation and finding the locations on maps make the latitudes and longitudes for these few species rather vague. The latitude and longitude information included in 


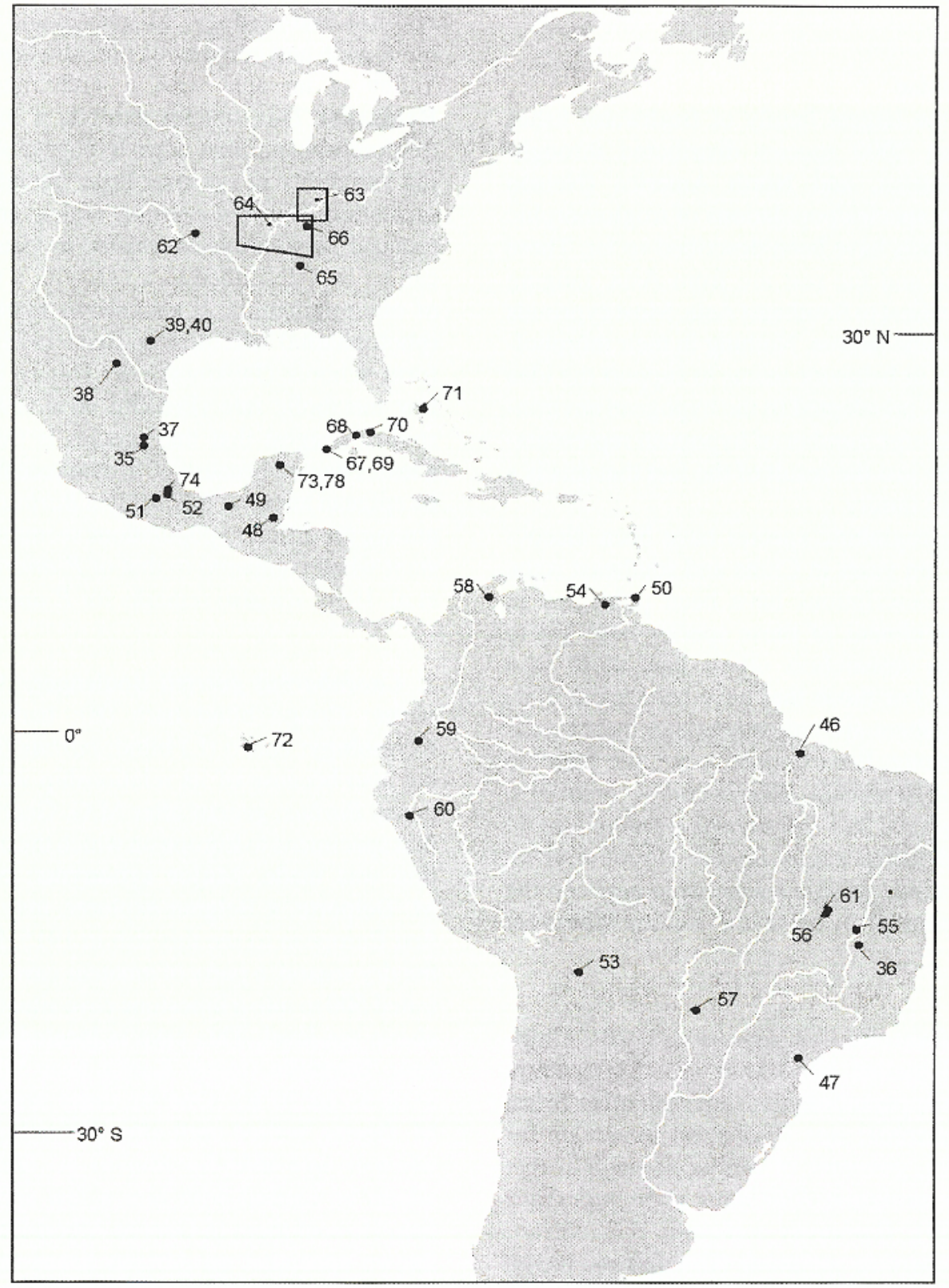

Figure 2. Localities and distributional areas for troglomorphic fishes in the American continent. Numbers represent species as cited in the text.

the article is the same as that which was used in the creation of the maps; where 'ca.' appears before the latitude and longitude, it means that it was determined using an atlas and should reflect a slightly lesser degree of accuracy. The reader should, therefore, take several things into consideration when using these maps. The maps are on a global scale and are intended to do little more than provide a general idea of where these species are located and provide a reference to the species numbers as described in the article. The nature of the methods used and the scale of the maps mean that the dots are not always (though in some cases are accurate to the tenth of a second) in the exact location. 


\section{Results}

Family: Cyprinidae

Cyprinidae is the largest family of freshwater fishes with more than 2000 species distributed throughout Eurasia, Africa, and North America (Nelson 1994). Eighteen species/populations of troglomorphic hypogean cyprinids have been described so far. Three are from Africa and the rest are from Asia, ranging from the Middle East to Southeast Asia. Most cyprinids have scales to some degree. Nothing in their morphology, physiology or behavior seems to support the idea of a family being preadapted to the hypogean environment. Thus, the large number of hypogean representatives seems to be just the result of the fact that this is a highly speciosed family.

Most of the troglobitic species have been discovered in the last ten years in China and southeast Asia. Many of their descriptions have been published in Chinese and specimens of those species have yet to be examined by researchers others than those who described them. For those that have been more thoroughly studied, there are indications that their taxonomy may be wrong. For example, it is quite possible that Barbopsis devecchii, Phreatichthys andruzzii, Caecobarbus geertsi and Iranocypris typhlops should all be assigned to the genus Barbus (Ercolini et al. 1982). A very close genetic relationship between the first two is supported by allozyme studies (Sbordoni et al. 1996).

1. Barbopsis devecchii Di Caporiacco, 1926. Common name: Somalian blind barb (E). Etymology: barb (L) for its apparent relationship with other fishes of the genus Barbus; ops (Gr) eyes; devecchii for C.M. De Vecchi, governor of Italian Somalia at that time. Major synonyms: Eilichthys microphthalmus (Pellegrin, 1929), Barbopsis stefaninii (Gianferrari, 1930), and Zaccarinia stefaninii (Gianferrari, 1934). Also, the name was originally spelled once as devecchi and once as devecchii; named after De Vecchi, so devecchii is correct. History: Original description was based on 19 specimens collected in a well by two local doctors, G. Stefanini and N. Puccioni in the spring of 1925 (Di Caporiacco 1927). Because of variability in eye reduction, specimens of this species have been mistakenly assigned to several genera and species. Distribution: Several localities in northcentral Somalia (see Ercolini et al. 1982 for map and list of specific locations) (ca. $9^{\circ} 10^{\prime} 00^{\prime \prime} \mathrm{N}, 48^{\circ} 22^{\prime} 10^{\prime \prime} \mathrm{E}$ ).
Habitat and ecology: In springs and wells throughout a wide and continuous phreatic layer in the Nogal Valley in an area with a wide range of salinity. Remarks: This species exhibits a lower degree of troglomorphism than other hypogean species, including variability in eye size; little, but still present, pigmentation; thin but existing scales; and a somewhat reduced nervous system related to visual functions. It can be best described as a fish with a variable degree of microphthalmia. It also shows marked scotophilia (photophobia) (Ercolini \& Berti 1978) and does not form schools (Jankowska \& Thinès 1982). It has a low metabolic rate (Ercolini et al. 1987). Allozyme studies suggest that this species is troglomorphic to a lesser degree because of a more recent isolation from its epigean ancestor (probably a Barbus sp.) Gene flow among the different populations seems to be rather constant when compared to that of $P$. andruzzii (Sbordoni et al. 1996; see also remarks for $P$. andruzzii).

2. Caecobarbus geertsii Boulenger, 1921. Common name: Congo blind barb (E); barbu aveugle $(F)$. Etymology: caeco (L) blind; barbus (L) for its barbs but also because of its relationship with fishes of the genus Barbus; geertsi after M.G. Geerts who sent the first specimens to Europe on which the original description was made. Major synonyms: None. History: M. Delporte, a Belgian explorer, may have been the first European to see this fish in 1915. In 1917, during the dry season, a party of amateur cave explorers penetrated $500 \mathrm{~m}$ into a limestone cave situated about $700 \mathrm{~m}$ above sea level. This cave is located in lower Congo near Thysville (today Kanka near Mbanza-Ngungu, $\left.5^{\circ} 18^{\prime} \mathrm{S}, 14^{\circ} 50^{\prime} \mathrm{E}\right)$. One of those amateur explorers, M. Geerts, waited until after the end of World War I, when it was safe for him to go back to Belgium, where he carried with him a few specimens of this fish. He sent them to George Albert Boulenger, a well known specialist on African fishes (and a Belgian). E. Randour may have found this fish in other caves in the early $1920 \mathrm{~s}$. Being easy to transport alive, many European scientists did some experimental work with this species early on. It became so famous that in May 1951, it was exhibited at the New York Aquarium (Romero \& Benz 2000). Distribution: Congo, caves in the lower Congo river system (ca. $5^{\circ} \mathrm{S}, 15^{\circ} \mathrm{E}$ ) (see Heuts \& Leleup 1954 for a distributional map). Habitat and ecology: In caves characterized by cyclic food scarcity (Heuts 1951). Remarks: It has vestigial eyes that are not externally visible (Gerard 1936). It was 
the first troglomorphic species described outside the American continent. After Astyanax fasciatus, it is one of the most-studied hypogean fish. Despite numerous attempts, breeding in captivity has failed. It tends to aggregate based on conspecific odors (Berti \& Thinès 1980), is scotophilic (Thinès 1953), and responds to the alarm substance (Thinès \& Legrain 1973). This species seems to be related to primitive members of the genus Barbus (Heuts op. cit.)

3. Caecocypris basimi Banister \& Bunni, 1980 Common name: None given. Etymology: caeco (L) blind; cypris (L) because it is a cyprinid; basimi (L) after Basim M. Al-Azzawi, the collector of the specimens. Major synonyms: None. History: Collected for the first time by Basim M. Al-Azzawi, a collector with the Natural History Research Center of the University of Baghdad, on 21 October 1977 while visiting the locality of $T$. widdowsoni in order to collect specimens of the latter species. Distribution: Iraq, $\mathrm{Al}$ Anbar province, Al Hadithah, natural well in the Sheik Hadid shrine (ca. $34^{\circ} 04^{\prime} \mathrm{N}, 42^{\circ} 24^{\prime} \mathrm{E}$ ). Same as for $T$. widdowsoni. Habitat and ecology: Same as for T. widdowsoni with which it is found syntopically. Remarks: Eyeless with the orbit filled with fatty tissue; vestigial eyes are present only in juveniles. Depigmented. Scales present only in large specimens.

4. Garra barreimiae Fowler \& Steinitz, 1956. Common name: Omani blind cave fish (E). Etymology: barreimiae $(\mathrm{L})$ after the type locality, Barreimei, Oman. Major synonyms: None. History: The epigean form was first known from several specimens sent to the Academy of Natural Sciences of Philadelphia between 1950 and 1951. The first hypogean, troglomorphic population was discovered in May 1980 by Andy Dunsire and M. Gallagher who collected 100 dead and 56 live individuals (Banister et al. 1992). Distribution: Arabian peninsula, Oman, Barreimei. From a deep cave on the south flank of the Jabal Akhdar mountains, $9 \mathrm{~km} \mathrm{E.S.E.} \mathrm{of} \mathrm{Al-Hamra}\left(23^{\circ} 05^{\prime} \mathrm{N}, 57^{\circ} 21^{\prime} \mathrm{E}\right)$. Habitat and ecology: $\mathrm{pH}$ range $6.5-7.5$; $\mathrm{dH}$ range $10.0-20.0$. Remarks: No externally visible eyes. Depigmented. Optic lobes not fully developed. It has weak squamation. Some increased development of melanin and the optic lobes occurred among individuals exposed to light under artificial conditions.

5. Garra dunsirei Banister, 1987. Common name: None given. Etymology: dunsirei (L) after Andy
Dunsire, the collector. Major synonyms: None. History: The first four specimens were received at the British Museum (Natural History) in 1984 and were collected by A. Dunsire and D. Green on 16 May 1980. Another 19 live specimens were collected by C. Maclelland on 26 February 1983. Distribution: Oman, Dhofar, Jabal Qara (variously Jabal Samhan) mountains, in pools inside caves at the bottom of a large sinkhole at Tawi Atair $\left(17^{\circ} 06^{\prime} \mathrm{N}, 54^{\circ} 34^{\prime} \mathrm{E}\right)$. It seems to be very geographically isolated, even from any other species of fish; the closest species is found more than $600 \mathrm{~km}$ away. Habitat and ecology: The fish were caught in a pool in a side passage $200 \mathrm{~m}$ down a sink hole. Remarks: Eyes apparently normal. Depigmented. Less squamation than epigean $G$. barreimiae. There are only a few casual behavioral observations of this fish in captivity.

6. Iranocypris typhlops Bruun \& Kaiser, 1944. Common names: mahi-ye kurgar (Farsi), Iran cave barb (E). Etymology: iran (L) because it is found in Iran; cypris (L) because it is a cyprinid; typhlos $(\mathrm{Gr})$ blind; ops $(\mathrm{Gr})$ eye. Major synonyms: None. History: E.W. Kaiser collected seven specimens from a well in Kaaje-Ru, valley of $\mathrm{Ab}$-i-Serum, Iran, while researching fauna in the freshwaters of that country on 6 May 1937. Distribution: Iran, Lorestan (Khorramabad) province, Zagros mountains, Ab-i-Serum Valley near Tang-e-haft railway station, Baq-e-Loveh Oasis, a natural well at Kaaje-Ru $\left(33^{\circ} 05^{\prime} \mathrm{N}, 48^{\circ} 36^{\prime} \mathrm{E}\right.$ ) (for full locality description see Coad 1996). Habitat and ecology: The welllike water resurgence in which it has been found seems to be the result of a collapsed subterranean system. This is probably part of a larger but complex, narrow, and inaccessible network of underground waters. This locality is shared by another species of hypogean fish, Paracobitis smithi (see below). Remarks: This species is rare and may be endangered due to overcollecting in its only known locality (Coad op. cit.).

7. Phreatichthys andruzzii Vinciguerra, 1924. Common name: Somalian cavefish (E). Etymology: phreas (L) well; ikhthus (Gr) fish; andruzzii (L) for Alcibiade Andruzzii who secured the first specimens. Major synonyms: None. History: Six specimens were collected by lieutenant Zaccarini at Bud-Bud $\left(4^{\circ} 11^{\prime} 19^{\prime \prime} \mathrm{N}\right.$, $46^{\circ} 28^{\prime} 21^{\prime \prime}$ E), central Somalia. He gave them to a Alcibiade Andruzzi, a local physician who, in turn, sent them to the Museo Civico de Storia Naturale di Genoa. Since then, this species has been studied 
from morphological, ecological, and behavioral perspectives by a number of researchers (e.g., Berti \& Zorn 2001). Distribution: In central Somalia (see Ercolini et al. 1982 for map and list of specific localities) (ca. $4^{\circ} 11^{\prime} 50^{\prime \prime} \mathrm{N}, 46^{\circ} 28^{\prime} 00^{\prime \prime} \mathrm{E}$ ). Habitat and ecology: The different localities at which it is found have different levels of salinity within what probably is the same underground, karstic hydrographic system. Elevations of the wells range between 135 and $150 \mathrm{~m}$ a.s.l. Remarks: This species lacks visible eyes. Depigmented. Scaleless. Parts of the nervous system associated with vision are highly reduced in complexity. It exhibits specific chemical recognition (Berti 1990), responds to light (Ercolini \& Berti 1975), and has low oxygen consumption (Ercolini et al. 1987). Allozyme studies have suggested that this species and Barbopsis devecchii, another hypogean species of the same general area but allopatric to $P$. andruzzii, may have descended from the same hypogean ancestor (probably a primitive Barbus). Furthermore, the genetic distance between the two does not support the contention that they belong to different genera. Gene flow among the different populations of $P$. andruzzii is probably highly restricted or even absent (Sbordoni et al. 1996).

8. Poropuntius speleops (Roberts, 1991). Common name: None given. Etymology: speos (Gr) cave; ops $(\mathrm{Gr})$ eyes. Major synonyms: Barbus speleops (original description). History: It was collected by Phillip Chapman in April 1989. Distribution: Thailand, Tham Phu Khieo, Phu Khieo Wildlife Sanctuary $\left(16^{\circ} 02^{\prime} 05^{\prime \prime} \mathrm{N}, 101^{\circ} 32^{\prime} 10^{\prime \prime} \mathrm{E}\right)$, and in the nearby Tham Phathewada (Tham means cave). Habitat and ecology: The cave seems to be a major flood-sink during the rainy season. A small stream flowing directly into Tham Pathewada may provide the only permanent year-round input into the underground system. The fish seems to be very abundant, with 65 to 150 individuals per $100 \mathrm{~m}$ over $500 \mathrm{~m}$ of cave length. Remarks: Eyes are vestigial and pigmentation is reduced among adults. Generalized squamation.

9. Sinocyclocheilus anatirostris Lin \& Luo, 1986 Common name: duck-billed golden-line fish (E, translation from Chinese); cave dragon (E). Etymology: anatis (L) duck-like; rostris (L) beak. Major synonyms: None. History: No information available. Distribution: China, Guangxi, Ling-Yün and Le-Ye (ca. $24^{\circ} 45^{\prime} \mathrm{N}, 106^{\circ} 30^{\prime} \mathrm{E}$ ). Habitat and ecology: Found in two caves at about $30 \mathrm{~m}$ from their entrance at
$1.5 \mathrm{~m}$ in depth. Remarks: No externally visible eyes. Depigmented. Scaleless. Reduced swim bladder.

10. Sinocyclocheilus angularis Zheng \& Wang, 1990. Common name: golden-line angle fish (E, translation from Chinese). Etymology: angularis (L) because at the end of the posterior portion of the head there is a bone in a form of an angle. Major synonyms: None. History: First collected in June 1986 by Zheng and Wang. Distribution: China, Guizhou, Panxian county, Cave is located at $25^{\circ} 26^{\prime} \mathrm{N}, 104^{\circ} 45^{\prime} \mathrm{E}$, at $1540 \mathrm{~m}$ a.s.l. Habitat and ecology: Karstic cave. Remarks: Microphthalmic. Depigmented. Scales embedded.

11. Sinocyclocheilus anophthalmus Chen, Chu, Luo \& Wu, 1988. Common name: eyeless goldenline fish (E, translation from Chinese). Etymology: an (Gr) without; opthalmus (Gr) eyes. Major synonyms: None. History: Collected on 18 April 1986. Distribution: China, Yunnan, Yiliang county, subterranean river at $25^{\circ} 24^{\prime} \mathrm{N}, 103^{\circ} 27^{\prime}$ E. Habitat and ecology: Limestone cave. Remarks: Eyes not externally visible. Little pigmentation. The scales cover only part of the body.

12. Sinocyclocheilus cyphotergous (Dai, 1988). Common name: None given. Etymology: cypho (Gr) curved, convexed; $\operatorname{terg}(o)$ us (L) back, because of its humpback. Major synonyms: Gibbibarbus cyphotergous. History: No information available. Distribution: China, Guizhou province, Luodian county, cave at Daxiao Dong, village of Dajing (ca. $25^{\circ} 26^{\prime} \mathrm{N}, 106^{\circ} 47^{\prime} \mathrm{E}$ ). Habitat and ecology: $300 \mathrm{~m}$ from the entrance of the cave. Remarks: Microphthalmic. Depigmented.

13. Sinocychlocheilus furcodorsalis Chen, Yang \& Lan, 1997. Common name: crossed-fork back golden-line fish (E, translation from Chinese). Etymology: furco (L) forked; dorsalis (L) on the back, because the anterior part of the humpback is bifurcated. Major synonyms: None. History: Collected in September 1993 by the authors who described it. Distribution: China, Guangxi, in an underground river in Tiane County (ca. $25^{\circ} 00^{\prime} \mathrm{N}, 107^{\circ} 00^{\prime} \mathrm{E}$ ). Habitat and ecology: No information available. Remarks: No externally visible eyes. Depigmented. Scales on the body but not on the head. 
14. Sinocyclocheilus hyalinus Chen \& Yang in Chen, Yang \& Zhu, 1994. Common name: translucent golden-line barbel (E, translation from Chinese); hyaline fish (E, translation from Chinese). Etymology: late Latin hyalinus, from hyalinos $(\mathrm{Gr})$ of glass, referring to the transparency of the fish. Major synonyms: None. History: Two specimens were collected in June 1991. This may have been the first troglomorphic fish ever reported in print (Romero 2001). Distribution: China, Yunnan, Luxi county, Alu limestone caves $\left(24^{\circ} 33^{\prime} \mathrm{N}, 103^{\circ} 45^{\prime} \mathrm{E}\right)$. Habitat and ecology: In an underground river (Yusun River) of a cave of $625 \mathrm{~m}$ in length at an elevation of $1712.87 \mathrm{~m}$ a.s.l. Feeds on microscopic animals and aquatic insects. Remarks: No externally visible eyes. Depigmentated. Scaleless. May be related to the epigean S. angustiporus.

15. Sinocyclocheilus microphthalmus $\mathrm{Li}, 1989$. Common name: Small eye golden-line fish (E, translation from Chinese). Etymology: micro (Gr) small; ophthalmus (Gr) eyes. Major synonyms: None. History: $\mathrm{Li}$ collected it in 1986, between April and May. Distribution: China, Guangxi Zhuang autonomous region, Ling Yun county, karst cave at Luo-lou Village $\left(24^{\circ} 20^{\prime} \mathrm{N}, 106^{\circ} 49^{\prime} \mathrm{E}\right)$. Habitat and ecology: Karst cave from which a river flows. Remarks: Microphthalmic. Depigmented. Covered by large scales.

16. Troglocyclocheilus khammouanensis Kottelat \& Bréhier, 1999. Common name: paa kham khom (Laotian for 'fish which crosses the streams'). Etymology: trogle $(\mathrm{Gr})$ hole; cyclocheilus $(\mathrm{L})$ a generic name proposed for cyprinid fishes with which this genus is supposedly related; khammouanensis $(\mathrm{L})$ after the limestone formation where it was found. Major synonyms: None. History: Holotype collected 24 February 1998 by F. Bréhier. Only one specimen has been collected but more have been observed. Distribution: Laos, Khammouan province, Khoung Nam Dôn, resurgence of Nam Dôn (stream) near Ban Phôndou (village) $\left(17^{\circ} 33^{\prime} 50^{\prime \prime} \mathrm{N}, 104^{\circ} 52^{\prime} 20^{\prime \prime} \mathrm{E}\right)$. May have a wider distribution. Habitat and ecology: Cave. Swims close to the bottom and hides near the bottom. Remarks: No externally visible eyes. Depigmented. Body entirely scaled. Several rows of sensory papillae on lateral and dorsal sides of the head. May be related to species of the genus Cyclocheilichthys.
17. Typhlobarbus nudiventris Chu \& Chen, 1982. Common name: None given. Etymology: typhlo $(\mathrm{Gr})$ blind; barbus (L) for its relationship with the genus Barbus; nudi ventris (L) for the naked ventral portion. Major synonyms: None. History: Known from only three specimens. No other information available. Distribution: China, Yunnan province, Jian Jianshui county, known only from a sinkhole about $100 \mathrm{~m}$ below the surface at an altitude of $1450 \mathrm{~m}$, in Yangieba (ca. $23^{\circ} 39^{\prime} \mathrm{N}, 102^{\circ} 46^{\prime} \mathrm{E}$ ). Habitat and ecology: No information available. Remarks: No externally visible eyes. No known phylogenetic relationships except for the fact that it has been placed in the subfamily Barbinae.

18. Typhlogarra widdowsoni Trewavas, 1955 . Common name: Iraq blind barb (E). Etymology: typhlo (Gr) blind; garra (L) because of its close relationship to the genus Garra; widdowsoni (L) after A.G. Widdowson who secured the first specimens. Major synonyms: None. History: Dr. Donald and Mr. Khosraf, by request of Mr. A.G. Widdowson, all of them with the Iraq Petroleum Co., collected two specimens of these fish which ended up in the British Museum (Natural History) in July 1953. Three living individuals were later captured and also sent to that institution. Distribution: Iraq, in two caves, one about $8 \mathrm{~m}$ below ground, $10 \mathrm{~km}$ north of Haditha $\left(34^{\circ} 04^{\prime} \mathrm{N}\right.$, $42^{\circ} 24^{\prime} \mathrm{E}$ ), and the other, known as Pigeon Hole, is found about $8 \mathrm{~km}$ south of Haditha, near the Euphrates. Habitat and ecology: Little is known except that the type localities are large caves fed by underground streams. It shares its habitat with Caecocypris basini. Remarks: No externally visible eyes. Depigmented. Has scales only along the lateral line. The nervous system associated with vision is very much reduced. A few melanophores are present in the tissue between the optic lobes and the cerebellum. This species is slightly scotophilic (Marshall \& Thinès 1958). It is closely related to Garra rufa.

\section{Family: Cobitidae}

This is a family composed of more than 110 species of freshwater fishes from Eurasia and Morocco. They have a wormlike to fusiform body and are mostly bottom dwellers (Nelson 1994). Only one troglomorphic species has been described so far.

19. Protocobitis typhlops Yang, Chen \& Lan, 1994. Common name: None given. Etymology: proto 
(Gr) primitive; cobitis (L) a generic name for members of the subfamily Cobitinae; typhlos (Gr) blind; ops (Gr) eye. Major synonyms: None. History: Specimens collected in August 1991 by Lan Jia-Hu. Distribution: China, Guangxi, Duan county, Xiaao town $\left(24^{\circ} 15^{\prime} \mathrm{N}, 107^{\circ} 05^{\prime} \mathrm{E}\right)$. Habitat and ecology: In a cave at $210 \mathrm{~m}$ a.s.l. Remarks: No externally visible eyes. Depigmented. Scales rudimentary and only along the midline of the sides of the body. Lacks lateral line. It also lacks a bony swimbladder capsule, which may be a primitive character.

Family: Balitoridae

This is a family of freshwater species from Eurasia composed by more than 600 species. They have three or more pair of barbels. Some species are scaleless. Many tend to hide underneath rocks (Nelson 1994). They have 14 troglobitic representatives. Yang et al. (1994) mentioned a Oreonectes sp. for a limestone cave near Xiaao, Duan county, Guanxi, China, yet to be described.

20. Cryptotora thamicola (Kottelat, 1988). Common name: waterfall climbing cave fish of Thailand (E) Etymology: Cryptotora $(\mathrm{Gr})$ is a contraction of kryptos (hidden, an allusion to the hidden cave life of this monospecific genus) and balitora, the name-sake of the family; tham (L) transcription of the Thai word for cave; cola (L) colere, to inhabit. Major synonyms: Homaloptera thamicola (original description) (Kottelat 1998). History: First collected by J. Taylor on 7 May 1985. Distribution: Thailand, Mae Hong Son province, Susa Cave $\left(19^{\circ} 28^{\prime} \mathrm{N}, 98^{\circ} 08^{\prime} \mathrm{E}\right)$. Habitat and ecology: The holotype was found on a ledge, apparently climbing up a small waterfall about $0.6 \mathrm{~km}$ from the cave entrance. Remarks: No visible eyes. Depigmented except for some appendages. Scaleless.

21. Nemacheilus evezardi Day, 1872. Common name: hill stream loach (E). Etymology: not applicable. Major synonyms: Kottelat (1990) changed the generic status of this species to Indoreonectes but without explaining why. Singh \& Yazdani (1993) gave it the name of Oreonectes evezardi. History: At the British Museum there are two specimens of N. evezardi (BMNH 1960, p. 6.2, pp. 1-2) collected from 'a cave in India', one of which is fully pigmented and the other somewhat depigmented but apparently with normal eyes. Menon (1987) mentioned the existence of 13 specimens collected in Bhaje Cave, Karla, Poona, but without saying whether or not these fish displayed any troglomorphic characters. Distribution: India, Madhya Pradesh state, Bastar district, Kotumsar Cave $\left(18^{\circ} 52^{\prime} 09^{\prime \prime} \mathrm{N}, 81^{\circ} 56^{\prime} 05^{\prime \prime} \mathrm{E}\right)$ at $560 \mathrm{~m}$ a.s.1. (Kottelat 1990). Habitat and ecology: A cave subject to frequent flooding during the monsoon season. Remarks: Hypogean forms exhibit lower oxygen consumption than the epigean forms (Biswas 1991). The hypogean individuals also exhibit circadian and circannual rhythmicity (Biswas et al. 1990).

22. Nemacheilus starostini Parin, 1983. Common name: Kughitang blind loach (E). Etymology: starostini (L) after I.V. Starostin, a fish researcher and collector specialized in Turkmenia. Major synonyms: Noemacheilus (Troglobitis) starostini (original description), Paracobitis starostini (Weber, 2000). History: Seven live individuals and four preserved specimens were captured in December 1981 by V. Dolzansky, a member of a Moscow speleological expedition. The head of that expedition, Vladimir Maltsev, had first found the fish in that very sinkhole five years earlier and caught several specimens which were lost during shipment. Distribution: Turkmenistan, Chardzhou province, Khrebet Kughitang (mountains) (several sinkholes) (ca. $37^{\circ} 55^{\prime} \mathrm{N}$ $66^{\circ} 23^{\prime}$ E). Habitat and ecology: The type locality is a sinkhole of about $19 \mathrm{~m}$ in depth with a seasonally fluctuating water level. A large portion of the pool is exposed to light part of the time. The pool is connected to an underwater stream. Up to 40 fish can be observed at a time in the pool. They feed on insect larvae and small benthic crustaceans (Smirnov 1983). Remarks: No externally visible eyes. Depigmented. Scaleless. No swimbladder.

23. Nemacheilus troglocataractus Kottelat \& Géry, 1989. Common name: None known. Etymology: trogle $(\mathrm{Gr})$ hole; cataracta $(\mathrm{L})$ waterfall. Major synonyms: None. History: Collected in February 1986 by R. Brouquisse and in June 1986 by the Thais-Maros expedition. Distribution: Thailand, Kanchanabur province, Tham Sai Yok Noi [=Tham Nam Tok], $3 \mathrm{~km}$ north-northwest of Nam Tok $\left(14^{\circ} 15^{\prime} \mathrm{N}, 99^{\circ} 04^{\prime} \mathrm{E}\right)$ Habitat and ecology: Underwater stream. Syntopic with Pterocryptis buccata. Remarks: No externally visible eyes. Depigmented. Scales embedded. 
24. Oreonectes anophthalmus Zheng in Anonymous, 1981. Common name: None given. Etymology: an $(\mathrm{Gr})$ without; opthalmus (Gr) eyes. Major synonyms: Nemacheilus anophthalmus (Kottelat, 1988).

History: No information available. Distribution: China, Guangxi, Wuming county, Qifeng Shan (hill), Taiji Cave (ca. $23^{\circ} 06^{\prime} \mathrm{N}, 108^{\circ} 40^{\prime} \mathrm{E}$ ). Habitat and ecology: No information available. Remarks: No externally visible eyes.

25. Paracobitis longibarbatus Chen, Yang, Sket \& Aljancic, 1998. Common name: None given. Etymology: longi (L) long; barbatus (L) barbels. Major synonyms: None. History: The first three specimens were collected during February and March 1995 by a joint Slovenian-Chinese expedition. Distribution: China, Guizhou province, Libo county, in a cave $13 \mathrm{~km}$ northeast of the town of Libo (ca. $25^{\circ} 15^{\prime} \mathrm{N}$, $108^{\circ} 00^{\prime}$ E). Habitat and ecology: The cave contains both streams and lakes with a sandy/rocky bottom. Remarks: No externally visible eyes. Depigmented. Rostral and maxillary barbels are well developed. It is related to Paracobitis variegatus longidorsalis, which occurs in the same basin of Xijiang. They appear to be scotophilic.

26. Paracobitis smithi (Greenwood, 1976). Common name: blind loach (E). Etymology: smithi (L) after Anthony Smith who collected the first specimens. Major synonyms: Noemacheilus smithi (original description) (Nalbant \& Bianco, 1998). History: First collected in April 1976. Distribution: Iran, Lorestan (Khorramabad) province, Zagros mountains, Ab-iSerum Valley near Tang-e-haft railway station, Baqe-Loveh Oasis, a natural well at Kaaje-Ru $\left(33^{\circ} 05^{\prime} \mathrm{N}\right.$, $48^{\circ} 36^{\prime} \mathrm{E}$ ) (for full locality description see Coad 1996). Habitat and ecology: The well-like water resurgence in which it has been found seems to be the result of a collapsed subterranean system. This is probably part of a larger but complex, narrow, and inaccessible network of underground waters. Syntopic with Iranocypris typhlops (see above). Remarks: No externally visible eyes. Depigmented.

27. Schistura jarutanini Kottelat, 1990. Common name: Srisawat blind cave loach (E). Etymology: jarutanini (L) after Kitipong Jarutanin, who collected the first specimens. Major synonyms: None. History: First collected by K. Jarutanin in November
1987. Distribution: Thailand, Kanchanaburi province, Amphoe Sri Sawat, Tham (cave) Ba Dan (ca. $14^{\circ} 02^{\prime} \mathrm{N}$, $94^{\circ} 32^{\prime}$ E). Habitat and ecology: Underground stream. Remarks: Eyes reduced to absent. Slightly depigmented. Scales embedded.

28. Schistura oedipus (Kottelat, 1988). Common name: None given. Etymology: schistura $(\mathrm{Gr})$ or skhizeîn to split; oura $(\mathrm{Gr})$ tail, an allusion to forked caudal fin; oedipus for Oedipus, a mythic Theban king who tore out his eyes. Major synonyms: Nemacheilus oedipus (original description). History: The holotype and paratype were collected by J. Dunkley on 7 May 1985. Distribution: Thailand, Mae Hong Son province, Tham (cave) Nam Lang $\left(19^{\circ} 31^{\prime} \mathrm{N}, 98^{\circ} 09^{\prime} \mathrm{E}\right)$ (see Kottelat 1990 for distributional map). Habitat and ecology: An outflow cave with a stream which is probably part of Nam Lang, part of a karstic endoreic basin. Remarks: Microphthalmic. Depigmented. Scales embedded.

29. Schistura sijuensis Menon, 1987. Common name: None given. Etymology: sijuensis (L) after Siju, the name of the cave where they were discovered. Major synonyms: Noemacheilus sijuensis original combination/description; Noemacheilus Mesonoemachilus sijuensis on plate caption of original description; Mesonoemacheilus sijuensis. Pillai \& Yazdani (1977) refer to this hypogean fish as Nemacheilus multifasciatus, yet, but Talwar \& Jhingran (1991) consider them separate species, and when referring to $N$. multifasciatus make no mention of being found in a cave. History: The first cave individuals belonging to this species may have been reported by Hora (1924) who described three specimens as 'Nemacheilus sp.' from the 'Siju Cave, Assam, India'. One specimen, caught within $35 \mathrm{~m}$ of the cave mouth, showed coloration comparable to the epigean forms. Two others, netted about $550 \mathrm{~m}$ from the entrance of the cave, were paler in color and apparently had reduced eyes. Distribution: India, Meghalaya, Garo Hills, Siju Cave (ca. $25^{\circ} 25^{\prime} \mathrm{N}, 90^{\circ} 30^{\prime} \mathrm{E}$ ). Habitat and ecology: No information available. Remarks: Eye size and pigmentation variable.

30. Sundoreonectes tiomanensis Kottelat, 1990. Common name: None given. Etymology: tiomanensis (L) after Pulau Tioman, the type locality. Major synonyms: None. History: First collected by Mark 
Day on 17 August 1988. Distribution: Malaysia, Pulau Tioman (island), cave in Mount Gunung Kajang at $1000 \mathrm{~m}$ a.s.l. (ca. $2^{\circ} 50^{\prime} \mathrm{N}, 104^{\circ} 15^{\prime} \mathrm{E}$ ). Habitat and ecology: In shallow pools of a small granitic cave system. Remarks: Reduced, partly embedded eyes. Partially depigmented.

31. Triplophysa gejüuensis (Chu \& Chen, 1979). Common name: Gejiu blind loach (E). Etymology: gejiuensis (L) for the province of Gejiu. Major synonyms: Noemacheilus gejiuensis (original description) (Zhou \& Cui, 1997), Schistura gejiuensis (Zhu, 1989). History: The seven original specimens were captured on 30 March 1978. Distribution: China, Yunnan province, Gejiu county, Bajiaojing near Qiafang $\left(23^{\circ} 16^{\prime} \mathrm{N}, 103^{\circ} 09^{\prime} \mathrm{E}\right)$. Habitat and ecology: In subterranean waters at a depth of $400 \mathrm{~m}$ underground. Remarks: No externally visible eyes. Depigmented. Scaleless. Has no swimbladder. It was classified as a new species based only on troglomorphic characters. Paired fins and barbels are greatly elongated.

32. Triplophysa shilinensis (Chu \& Yang in Chen, Yang \& Xu, 1992). Common name: blind loach (E). Etymology: shilinensis (L) for the words Shi Lin which in Chinese means 'stone forest', the name of the general area where this species is found. Major synomyms: None. History: The first two specimens were collected by the authors describing the species on 18 March 1991. Distribution: China, Yunnan, Lunan county, cave at Weiboyi village near Stone Forest $\left(24^{\circ} 47^{\prime} \mathrm{N}, 103^{\circ} 22^{\prime} \mathrm{E}\right)$. Habitat and ecology: The cave has a funnel-like opening and goes down vertically for $109 \mathrm{~m}$ before it reaches a horizontal river where this fish can be found. Insects have been found in their stomachs. Remarks: Eyes completely degenerated. Completely depigmented; body described as 'translucent'. Scaleless. Posterior chamber of air bladder reduced, and anterior chamber enclosed in a bony capsule.

33. Triplophysa xiangxiensis (Yang, Yuan \& Liao, 1986). Common name: None given. Etymology: xiangxiensis $(\mathrm{L})$ because it is found in the area of Xiangxi. Major synonyms: Noemacheilus xiangxiensis (original description), Schistura xiangxiensis (in Zhu, 1989). History: No information available. Distribution: China, Xiangxi, Hunan province, Longshan county, Feihu Cave (ca. $27^{\circ} 52^{\prime} \mathrm{N}, 102^{\circ} 15^{\prime} \mathrm{E}$ ). Habitat and ecology: Subterranean waters, Yuan River system, $20 \mathrm{~m}$ underground. Remarks: No externally visible eyes.

34. Triplophysa yunnanensis Yang, 1990. Common name: None given. Etymology: yunnanensis (L) because it is found in the province of Yunnan. Major synonyms: None. History: No information available. Distribution: China, Yunnan province, Yiliang (ca. $25^{\circ} 00^{\prime} \mathrm{N}, 103^{\circ} 23^{\prime} \mathrm{E}$ ). Habitat and ecology: No information available. Remarks: Microphthalmic but pigmented.

\section{Family: Characidae}

This is a highly diversified (ca. 900 species) family of freshwater fishes from America and Africa (Nelson 1994). They show no apparent morphological and/or behavioral preadaptation to the hypogean environment. It is somewhat surprising that more representatives of this family have not been found in caves given its ample distribution and high diversity. Most characids are completely covered with cycloid scales. There are at least two species of troglomorphic characids.

35. Astyanax fasciatus species complex (Cuvier 1819). Common name: Mexican blind/cave tetra (E). Etymology: not applicable. Major synonyms: The epigean form of this species was originally described by Cuvier (1819, p. 352, pl. 26 (figure 2) as Chalceus fasciatus based on material from Brazil. The genus Astyanax was created by Baird \& Girard (1854) and then the species was reassigned to it. The specific status of the epigean form in the areas surrounding the cave localities for the troglobitic ones is in dispute. The whole family Characidae is very complex, with many species that are difficult to differentiate from each other and are not always allopatric (Géry 1977, Nelson 1994). New species of the genus Astyanax have been described in Mexico using morphological characters only (e.g., Contreras-Balderas \& Lozano-Vilano 1988, Lozano-Vilano \& Contreras-Balderas 1990). Common synonyms are A. mexicanus, a rearrangement of Tetragonopterus mexicanus (De Filippi, 1853), and Astyanax fasciatus mexicanus. The use of mexicanus has been most commonly employed by US-based authors, especially when dealing with epigean individuals from Texas. However, clear taxonomic differences and geographic limits between A. fasciatus and A. mexicanus have yet to be established. Until the taxonomy of the entire genus is fully clarified, the most parsimonious approach is to use the name Astyanax 
fasciatus, clarifying when necessary whether we refer to the epigean or troglobitic populations. We avoid the use of the term 'cave populations' because some hypogean individuals are actually eyed and pigmented. History: The first cave, troglobitic population (from La Cueva Chica in the San Luis de Potosí area) was described as Anoptichthys jordani (Hubbs \& Innes, 1936), the second one (from La Cueva El Pachón) was named Anoptichthys antrobius (Alvarez, 1946), and a third one (from La Cueva de Los Sabinos) was named Anoptichthys hubbsi (Alvarez, 1947). Most if not all of the papers that still use either those names, or a combination of Astyanax and the specific names given to cave populations, are written by experimentalists, not field or taxonomic researchers. As more cave populations were discovered it became evident that this typological approach was creating a lot of confusion (Romero 2001). Distribution: The epigean A. fasciatus is a freshwater fish with a broad distribution in the New World. Although obligatory and facultative cave populations of the eyed form have been reported for Belize and Costa Rica (Romero 1984), the Yucatán Peninsula (Hubbs 1938), and Brazil (Trajano 2001 a), the only region in which they have developed into blind, depigmented individuals is the San Luis de Potosí area, east central Mexico, where at least thirty-one caves supporting subterranean populations of this fish can be found (Espinasa et al. 2001) (ca. $\left.22^{\circ} 05^{\prime} \mathrm{N}, 99^{\circ} 00^{\prime} \mathrm{W}\right)$. Not all the cave populations of this area display the same degree of morphological divergence from the surface forms, however. Some are completely blind and depigmented while others are only partially so. Three caves contain only individuals with full eyes and pigmentation. Eleven of these populations include blind, eyed, as well as phenotypically intermediate forms (Mitchell et al. 1977, Romero 1983, Espinasa et al. op. cit.). Habitat and ecology: In numerous caves. Some of those caves appear to be very poor from a trophic viewpoint while others (e.g., La Cueva Chica) have a very rich input of nutrients thanks to large bat colonies producing guano on which these fish feed. Remarks: Troglomorphic individuals have reduced eyes (most are not externally visible), pigmentation (including totally depigmented), and a larger number of taste buds (Schemmel 1967). The surface and cave forms interbreed in both natural and laboratory conditions, producing fertile hybrids with a phenotypically intermediate form in the $F_{1}$ generation, and with an $F_{2}$ generation whose individuals range from an almost completely blind and depigmented form to an almost eyed and pigmented one (Peters \& Peters 1973, Sadoglu 1957, Wilkens 1969). Breeding, electrophoretic, and karyotypic studies support the contention that the cave and epigean forms are the same species (Avise \& Selander 1972 Kirby et al. 1977). The two forms are not only different in their morphology, but also in their behavior: unlike the surface/eyed form, the blind form never schools, is active all the time, and is not aggressive (Boucquey et al. 1965, Breder 1942, Breder \& Gresser 1941, Erckens \& Weber 1976). Although the blind form does produce an alarm substance, it does not respond to it (Pfeiffer 1966). Schemmel (1980) also reported differences between the two forms in the angle of inclination used when feeding from the bottom. Differences in the level of phototactic responses among different populations have also been reported (Romero 1985).

36. Stygichthys typhlops Brittan \& Böhlke, 1965. Common name: Brazilian blind characid (E). Etymology: stygos (Gr) from the underworld in the Greek mythology; ichthyos (Gr) fish; typhlos (Gr) blind; ops (Gr) eye. History: Known from only one specimen captured on 16 May 1962 by Joseph A. Tosi, Jr., an ecologist with the Instituto de Agricultura of the Organization of American States. The fish was captured in water brought up from a depth of $30 \mathrm{~m}$ during a well-drilling operation. Distribution: Brazil, Minas Gerais state, in one well location at Jaiba. The precise location is unknown. Jaiba may refer to an area (Serra de Jaíba) or to a town, near to which the well could be situated. It is the area between Januaria and Janaúba, in northern Minas Gerais State, centraleastern Brazil (Trajano personal communication) (ca. $16^{\circ} 15^{\prime} \mathrm{N}, 44^{\circ} 00^{\prime} \mathrm{W}$ ). Habitat and ecology: Groundwater, obtained from a well drilled at $30 \mathrm{~m}$. Although the tooth structure seems to indicate a mostly vegetarian diet, it is unlikely that they maintain such a diet in the underground environment. This may be a relictual morphological feature. Remarks: No externally visible eyes. There is no distinct lateral-line system. Totally depigmented. Unlike the Mexican cave tetra, the ancestral form of this fish has yet to be determined. The Brazilian blind characid has a number of features typical of the Tetragonopterinae. More specifically, it may be related to the Hyphessobrycon-Hasemania complex, because of this group's reduction in the circumorbital bones; however that just may be a coincidence given that the reduction of those bones is a convergent feature among cave fishes. They also differ from other Tetragonopterinae in the large number of inner 
premaxillary and maxillary teeth, as well as the small number of anal rays which is unusual for this group of characids (Romero \& McLeran 2000).

\section{Family: Ictaluridae}

About 45 species of freshwater fishes found in North America from southern Canada to Guatemala. They are scaleless (Nelson 1994). Their possession of barbels as well as their nocturnal habits might be argued to be preadaptive features. Four unrelated eyeless species are known from deep wells and caves. All four species show a remarkable convergence of features that include the lack of externally visible eyes, depigmentation, and reduced lateral line (Walsh \& Gilber 1995).

37. Prietella lundbergi Walsh \& Gilbert, 1995. Common name: phantom blindcat $(\mathrm{E})$; bagre ciego duende (S). Etymology: lundbergi (L) after John G. Lundberg, an American ichthyologist who has greatly contributed to the systematics and paleontology of ictalurid and neotropical catfishes. Major synonyms: None. History: Collected by T. Morris on 17 April 1989. Distribution: Mexico, Tamaulipas state, Río Tamesí drainage, Nacimiento (spring) de San Rafael de Los Castros, subsurface thermal spring (ca. $22^{\circ} 40^{\prime} \mathrm{N}, 99^{\circ} 00^{\prime} \mathrm{W}$ ). Habitat and ecology: Cave subject to periodic flooding. Remarks: No visible eyes. Depigmented. Reduced lateral line.

38. Prietella phreatophila Carranza, 1954. Common name: Mexican blindcat (E), bagre ciego de Múzquiz (S). Etymology: prietella (L) after Carlos Prieto, sponsor of the expedition to collect these specimens; phreas (L) well; philos (Gr) loving, with affinity to. Major synonyms: None. History: Collected on August 1954 by J. Carranza after hearing of the presence of a blind catfish in a well in that area. Distribution: Several localities in northern Mexico. Original specimens collected at El Potrero de Doña Mariana, Municipio Múzquiz, Cohauila state, in a well at the base of Sierra de Santa Rosa (ca. $27^{\circ} 55^{\prime} \mathrm{N}, 101^{\circ} 07^{\prime} \mathrm{W}$ ). Habitat and ecology: It has been kept under starvation in the laboratory for up to 44 months and it is believed that it may last longer under natural conditions, which suggests that its environment is very poor in nutrient (Hendrickson et al. 2001). Remarks: No externally visible eyes. Depigmented. Reduced lateral line. It has a swimbladder.
39. Satan eurystomus Hubbs \& Bailey, 1947. Common name: widemouth blindcat (E). Etymology: satan (Heb) prince of darkness; eury (Gr) broad; stomus (Gr) mouth ('widemouth prince of darkness') (Hubbs liked to name cave fishes with diabolic names based on the idea of hell being underground; see etymology for Ophisternon infernale). Major synonyms: None. History: Carl L. Hubbs visited the Witte Memorial Museum in San Antonio, Texas in 1938 when the director of that museum, Ellen S. Quillin, made available to him two blind catfishes which had been pumped from deep artesian wells in the vicinity of San Antonio. One of them was Trogloglanis pattersoni but the other one was of an unknown species. Apparently these fish had been pumped out of wells since the 1920s. Distribution: Texas, Edwards Aquifer. Holotype collected at an artesian well (depth $381 \mathrm{~m}$ ), near San Antonio, Bexar county (ca. $29^{\circ} 30^{\prime} \mathrm{N}, 98^{\circ} 30^{\prime} \mathrm{W}$ ). Habitat and ecology: An opportunistic predator. Remarks: No externally visible eyes. Depigmented. Exhibits degeneration of the swimbladder.

40. Trogloglanis pattersoni Eigenmann, 1919. Common name: toothless blindcat (E). Etymology: troglo (Gr) cave; glanis (Gr) catfish, originally from Glanis, the name of a river; pattersoni (L) after J.T. Patterson who secured the first specimen. Major synonyms: None. History: The holotype was colfected on an unknown date by G.W. Brackenridge of San Antonio, Texas, the owner of the well. He gave the specimen to Patterson who, in turn, sent it to Eigenmann. A second specimen was caught in June 1934 by Josef Boecke in a ditch fed by an artesian well on his farm NE to San Antonio, Texas, and a third one was collected sometime before 1955 near Von Ormy, Texas. Distribution: Texas, Edwards Aquifer (ca. $29^{\circ} 30^{\prime} \mathrm{N}$, $98^{\circ} 30^{\prime} \mathrm{W}$ ). Habitat and ecology: Found in artesian waters up to $1300 \mathrm{~m}$ deep. This species is a herbivore, feeding on fungal growth and detritus found in the wells. Temperature may be a limiting factor in the distribution of this fish (Longley \& Karnei 1979). It may be a scavenger. Remarks: Blind. Depigmented. Exhibits rudimentation in a number of regions of the nervous system related to vision.

Family: Siluridae

About 100 species of freshwater in Europe and Asia. Most are scaleless. Silurids have one or two pairs of barbels (Nelson 1994). The presence of barbels and 
nocturnal habits could be considered preadaptations. One, maybe two troglomorphic species from southeast Asia.

41. Pterocryptis buccata Ng \& Kottelat, 1998. Common name: None given. Etymology: bucca (L) mouth, because their cheeks look inflated due to their musculature. Major synonyms: None. History: The hypogean individuals were collected by L. Deharveng and colleagues in June 1986. Distribution: Thailand, Kanchanaburi province, Amphoe Sai Yok, Mae Khlong basin (ca. $14^{\circ} 15^{\prime} \mathrm{N}, 99^{\circ} 04^{\prime}$ E). Habitat and ecology: Syntopic with Nemacheilus troglocataractus. Remarks: There are both epigean and hypogean populations. The hypogean individuals are depigmented and have sunken eyes.

42. Pterocryptis cucphuongensis (Mai, 1978). Common name: Cá niêt Cúc phurong (Vietnamese). Etymology: cucphuongensis (L) after Cúc phurong National Park where the fish was found. Major synonyms: Silurus cucphuongensis (in original description). New name given by $\mathrm{Ng} \&$ Kottelat (1998). History: Collector and date unknown. Distribution: Vietnam, Cuc Phurong National Park, foothills of the northern Annamite Mountains, some $100 \mathrm{~km}$ southwest of Hanoi. The park comprises parts of $\mathrm{Ha}$ Nam Ninh, Ha Son Binh and Thanh Hoa provinces $\left(20^{\circ} 19^{\prime} \mathrm{N}, 105^{\circ} 22^{\prime} \mathrm{E}\right)$. Habitat and ecology: There is no information in the description that this fish is a hypogean one. Remarks: It is microphthalmic. Description based on a single individual that may have not been well preserved. Based on the original description, it is not clear why this fish has been labeled as a 'cave fish' (e.g., Weber 2000).

Family: Clariidae

This family includes about 100 species of freshwater fishes found in Africa, Syria and southern and western Asia (Philippines to Java). They have four pairs of barbels and are scaleless. Airbreathing is accomplished with a labyrinthic organ arising from the gill arches ('labyrinth catfishes'). Some species are capable of traveling over short distances on land ('walking catfishes'). Some are burrowers with small eyes (Nelson 1994). These could be considered as preadaptations to the hypogean life. Three troglomorphic species have been described so far.
43. Clarias cavernicola Trewavas, 1936. Common name: cave catfish (E); spelonkbaber (Afrikaans); blinderhöhlenwels $(\mathrm{G})$. Etymology: cavernicola $(\mathrm{L})$ living in a cave. Major synonyms: None. History: It may have been encountered first between 1917 and 1919 by geologists Jaeger \& Waibel (1921). First collected by Karl Jordan who visited that cave in 1921 but not described until 1936. Distribution: Namibia, known only from a underground lake at Aigamas Cave, north of Otavi and west of Grootfontein ( $\left.19^{\circ} 25^{\prime} \mathrm{S}, 17^{\circ} 18^{\prime} \mathrm{E}\right)$ Habitat and ecology: Lives in caves over shelves in open, clear water. Usually swims near the surface of the water. Feeds on the remains of insects (mostly beetles), bat and baboon guano, and insects associated with animal carcasses (Bruton 1995). Remarks: Eyes not visible but sunken and with variability in development. Depigmented.

44. Horaglanis krishnai Menon, 1950. Common name: Indian blind catfish (E). Etymology: hora (L) after S.L. Hora, Director of the Zoological Survey of India; glanis (L) catfish; krishnai (L) after the collector N. Krishna. Major synonyms: None. History: Four specimens were collected in July 1948 by N. Krishna Pillay after draining a well. He gave the specimens to K. Gopinath, who in turn sent it to Hora. The two specimens were received in August 1949 and the other two were lost. Distribution: India, Kerala state, Travancore, in two dugout wells at Koitayam (between $8^{\circ} 04^{\prime} \mathrm{N}, 76^{\circ} 13^{\prime} \mathrm{E}$ and $10^{\circ} 21^{\prime} \mathrm{N}, 77^{\circ} 38^{\prime} \mathrm{E}$ ) (Mercy et al. 1982). Habitat and ecology: No information available. Syntopic with Monopterus indicus (Eapen, 1963). Remarks: No externally visible eyes. Free, not enclosed, swimbladder. It has a bulbous stomach that helps store food and the ileo-sphincter helps retain the digested food to maximize absorption (Mercy \& Pillai 1984-5).

45. Uegitglanis zammaranoi Gianferrari, 1923. Common name: None given. Etymology: uegit (L) after the type locality, a pool in Uegit, El Uegit, Somalia; glanis (L) eponymous spirit of the Sacred springs in the town of Glanum in Provence, then there was the Glanicae, a triad of local Mother Goddesses associated with healing springs (all this makes reference to the fact that the this fish was found in a pool associated with a spring); zammaranoi (L) after the collector, V.T. Zammaranoi. Major synonyms: None. History: The first specimens were collected by an Italian army officer, V.T. Zammaranoi at an unspecified 
date. Distribution: Somalia, several localities in southern Somalia (see Ercolini et al. 1982 for distributional map) (ca. $3^{\circ} 48^{\prime} 30^{\prime \prime} \mathrm{N}, 43^{\circ} 14^{\prime} 47^{\prime \prime}$ E). Habitat and ecology: Tolerates remarkable variations in salinity and chemicals in the water. It reproduces between January and March, in the dry season (Ercolini et al op. cit.). Remarks: No externally visible eyes. Depigmented. Scaleless. It lacks optic nerves, chiasm, and has a reduced brain size, particularly in the optic lobe and cerebellum (Bianchi 1975, Ercolini \& Berti 1977). The epidermis has cells that contain an alarm substance. It does not present any specialization in olfactory structures (Bianchi et al. 1978). Displays aggressive behavior similar to epigean Siluriformes (Berti \& Ercolini 1979). Studies on their responses to light have been inconclusive (Ercolni \& Berti op. cit.).

Family: Pimelodidae

This is a family of about 300 species of freshwater fishes found in Central and South America (north to southernmost Mexico). They have three pairs of barbels and a naked body. Barbels and nocturnal habits make members of this family preadapted to the hypogean environment (Nelson 1994).

Seven troglomorphic species have been described so far. Additionally, Hubbs (1936, 1938) reported specimens of $R$. guatemalensis with certain degree of depigmentation and eye reduction and called them Rhamdia guatemalensis decolor and Rhamdia guatemalensis stygaea, respectively. The four other species/populations of Rhamdia described for southern Mexico and Belize represent a puzzle not only because of their close similarity to epigean Rhamdia, but also because of their great variability in troglomorphic characters and the lack of molecular studies that could shed some light on their evolution. There may be at least two more species of stygobiontic representatives for this family. One reported as Imparfinis sp. by Trajano (1997c) for the caves in the Chapada Diamantina, Itaete County, Bahia State, Brazil, and a Taunayia sp. also reported by Trajano (op. cit.) for Brazil, Bahia state, Campo Formoso County, Toca do Gonçalo Cave.

46. Phreatobius cisternarum Goeldi, 1905. Common name: None given. Etymology: phreatos $(\mathrm{Gr})$ from a spring; bius $(\mathrm{Gr})$ alive; cisternarum $(\mathrm{L})$ from a deposit; all this in reference to the phreatic origin of this fish. Major synonyms: Heptaterus cisternarum (Andreas Buckup, 1988). The date of publication is usually cited as 1904, year in which Goeldi presented the paper describing this species before the Sixth International Congress of Zoology at Berne. However, the proceedings of that meeting were not published until 1905 and, according to article 21.1 of the International Code of Scientific Nomenclature it is the date of publication that must be taken in consideration. History: No information available. Distribution: Brazil, Pará and Amapá states, at the Rio Amazonas delta, Belém city, Pará, and Macapá city. Original locality: Marajo I., at the mouth of the Amazon, Brazil (in a cistern) (ca. $1^{\circ} 27^{\prime} \mathrm{S}$, $48^{\circ} 29^{\prime}$ W). Habitat and ecology: Phreatic. Remarks: Rudimentary eyes. Reduced pigmentation, mostly in the head and anterodorsal parts of the body. Its taxonomic position is very much in question (de Pinna 1998).

47. Pimelodella kronei (Miranda-Ribeiro, 1907) Common name: ceguinho (P). Etymology: kronei (L) after Ricardo Krone, who first reported this fish to Miranda-Ribeiro. Major synonyms: Typhlobagrus kronei (original description); Caecorhamdella brasiliensis (Borodin, 1927), Pimelodella lateristriga var. kronei (Haseman, 1911). History: This fish may have been known for some time, since the paper describing it has two pictures of the type locality dated 1898 and taken by Krone. Distribution: Brazil, southern São Paulo state, Upper Riö Ribeira basin, Iporanga, Areiras, ÁguasQuentes, Bombas, and Córrego Seco caves, on the right margin of the Rio Betari, and Alambari de Cima and Guruvuta caves, on the left margin $\left(24^{\circ} 25^{\prime} \mathrm{S}, 48^{\circ} 35^{\prime} \mathrm{W}\right)$. Habitat and ecology: Headwater streams, with rocky beds and rapids intercalated with soft-bottomed pools. Remarks: Variable vestigial eyes. Varying pigmentation from dark to almost totally depigmented with most individuals being intermediate. They display agonistic behavior (Trajano 1991). Telencephalon is enlarged probably due to the improvement of olfactory and integrative centers related to social communication. Its putative ancestor is Pimelodella transitoria.

48. Rhamdia laticauda typhla Greenfield, Greenfield \& Woods, 1982. Common name: cave chulín (E). Etymology: typhla (Gr) blind. Major synonyms: None. History: First specimens were collected on 10 July 1972. Distribution: Belize, Mountain Pine Ridge, Las Cuevas $\left(16^{\circ} 45^{\prime} \mathrm{N}, 89^{\circ} 00^{\prime} \mathrm{W}\right)$. Habitat and ecology: Found in pools together with troglomorphic shrimps. Remarks: Variable eye size and 
pigmentation. The $R$. guatemalensis reported by Hubbs $(1936,1938)$ showed a certain degree of depigmentation and eye reduction and was called Rhamdia guatemalensis decolor and Rhamdia gualtemalensis stygaea, respectively; yet these subspecies show a much lesser degree of depigmentation and eye reduction than $R$. laticauda typhla.

49. Rhamdia macuspanensis Weber \& Wilkens, 1998. Common name: None given. Etymology: macuspanensis (L) after the town of Macuspana, about $20 \mathrm{~km}$ from the type locality. Major synonyms: None. History: The first specimen was provided by V. Sbordoni and specimens used for the species description were collected on 11 April 1996 by Ulrike Strecker, Axel Werber and Horst Wilkens. Distribution: Mexico, Tabasco state, ca. $20 \mathrm{~km}$ southeast of Macuspana, Grutas de Agua Blanca, Balneario de Agua Blanca at $64.9 \mathrm{~km}$ of the road (carretera federal 186) from Villahermosa to Chetumal $\left(17^{\circ} 37^{\prime} 15.5^{\prime \prime} \mathrm{N}, 92^{\circ} 28^{\prime} 22.6^{\prime \prime} \mathrm{W}\right)$. Habitat and ecology: Crustaceans and epigean Rhamdia have been observed in the same cave. Remarks: Sunken eyes. Reduced pigmentation.

50. Rhamdia quelen (Quoy \& Gaimard, 1824). Common name: eyeless catfish of Trinidad (E). Etymology: not applicable. Major synonyms: Caecorhamdia urichi (description of the cave population, Norman, 1926); R. quelen urichi, Caecorhamdella urichi (Hubbs, 1938). History: Cave individuals were first collected by Friederick William Urich in the 'Guacharo' cave (actually Oropouche or Urumaca cave). By July 1924, the British Museum of Natural History had received from Urich a specimen of 'blind' fish. The fish was examined by John Roxborough Norman who, fearing that the specimen could represent an accident of nature rather than a normal fish species, requested two more specimens and Urich complied. In October of 1926 Norman published his paper and named the fish Caecorhamdia urichi $[$ caeco (L) blind; rhamdia $(\mathrm{L})$ the genus of a catfish to which this cave fish seemed most related to; urichi (L) honoring Urich, the collector] (Romero \& Creswell 2000). Distribution: Trinidad and Tobago, Trinidad, northern range, Pool at about $70 \mathrm{~m}$ from the entrance to the Oropouche or Urumaca cave $\left(10^{\circ} 42^{\prime} 53^{\prime \prime} \mathrm{N}, 61^{\circ} 10^{\prime} 29^{\prime \prime} \mathrm{W}\right)$. Habitat and ecology: The cave is linear and limestone with an emergent stream running its full length. It is at an altitude of $185-215 \mathrm{~m}$ a.s.l. Fish are only found in the dark section of the cave. They feed on the droppings of oil birds, Steatornis caripensis. Remarks: There is some variability in eye size and pigmentation but even the ones with the least visible eyes cannot be considered anything but microphthalmic. Fish are extremely scotophilic (Romero \& Creswell op. cit.).

51. Rhamdia reddelli Miller, 1984. Common name: juil ciego (S). Etymology: reddelli (L) after James R. Reddell who donated all the type specimens. Major synonyms: Considered just a population of Rhamdia laticauda by Silfvergrip (1996). History: Holotype collected on 9 March 1973. Distribution: Mexico, Oaxaca state, ca. $9 \mathrm{~km}$ southwest of Acatlán, Cueva del Nacimiento del Río San Antonio (ca. 18 $12^{\prime} \mathrm{N}$, $\left.98^{\circ} 02^{\prime} \mathrm{W}\right)$. Habitat and ecology: In a deep lake about $120 \mathrm{~m}$ from the entrance of the cave. The cave is at $100 \mathrm{~m}$ a.s.l. A rich invertebrate troglomorphic fauna is found in the same cave. Remarks: No externally visible eyes. Depigmented. Individuals will darken under light conditions.

52. Rhamdia zongolicensis Wilkens, 1993 Common name: None given. Etymology: zongolicensis (L) after Zongolica, the geographic region where it occurs. Major synonyms: According to Silfvergrip (1996) it is a local population of Rhamdia laticauda. History: Collected on 17 December 1992 by Ulrike Strecker and Horst Wilkens. Distribution: Mexico, Veracruz state, Sierra de Zongolica, Cueva del Ostoc or Cueva de El Túnel (ca. $18^{\circ} 30^{\prime} \mathrm{N}, 97^{\circ} 10^{\prime} \mathrm{W}$ ). Habitat and ecology: No other aquatic fauna has been reported for the same cave. Remarks: Slightly depigmented. Individuals will darken under light conditions. This fish is extremely similar to $R$. laticauda but also to $R$. reddelli reason by which some authors (e.g., Silfvergrip op. cit.) do not consider it a valid species.

Family: Trichomycteridae

This is a family of about 160 species of freshwater fishes found in Costa Rica, Panama and South America. They have a naked and elongate body. They usually have two pairs of barbels on maxilla, but lack barbels on the chin (Nelson 1994). The presence of barbels and nocturnal habits of some species make them preadapted to the hypogean environment. Of the ca. 100 species of the genus Trichomycterus, three species/populations have been found to display troglomorphic characters while other non-troglomorphic, 
hypogean populations have been reported for the Colombian Andes (Sket 1988) and two more for Brazil (Trajano \& Souza 1994, Trajano 1997c).

53. Trichomycterus chaberti Durand, 1968. Common name: None given. Etymology: chaberti (L) after J. Chabert, collector of the first specimens. Major synonyms: Pygidium chaberti (Ringuelet, 1974). History: 30 specimens were collected by Chabert and his companions during a visit to the type locality on September 1966. An earlier specimen may have been captured by B. Antelo in August and sent to R.A. Ringulet but not described until 1974 (Ringuelet op. cit.). Distribution: Bolivia, Charcas province, Potosí department, Cave of Umayalanta, $8 \mathrm{~km}$ northwest of the town of Torotoro, $130 \mathrm{~km}$ south of Cochabamba (ca. $18^{\circ} 20^{\prime} \mathrm{S}$, $65^{\circ} 30^{\prime} \mathrm{W}$ ). Habitat and ecology: The cave is at an altitude of $2850 \mathrm{~m}$. The entrance is a sinkhole of $140 \mathrm{~m}$ in depth through which a body of water penetrates for $1620 \mathrm{~m}$. Remarks: Eye size and pigmentation are variable, from almost normal for a trichomycterid (which in comparison with other fishes appears to be microphthalmic to somewhat reduced) to a typical troglomorphic fish with very reduced, not externally visible eyes.

54. Trichomycterus conradi (Eigenmann, 1912). Common name: bagre ciego de la cueva del Guácharo (S). Etymology: not applicable. Major synonyms: Pygidium conradi (original description); $T$. guianensis (Galán, 1995). History: First reference to fishes from this cave is by Schultz (1949). Distribution: Venezuela, Monagas state, Cueva del Guácharo $\left(10^{\circ} 10^{\prime} 33^{\prime \prime} \mathrm{N}, 63^{\circ} 33^{\prime} 06^{\prime \prime} \mathrm{W}\right)$. Habitat and ecology: This is a large cave in which fish can be found throughout most of its waters. This fish has the tendency to burrow in the sediment, which may make its observation difficult (Romero 1987). Remarks: It has reduced eyes and variable pigmentation (Nalbant \& Linares 1987). Many of the morphological differences reported by Andreani Armas (1990) may be influenced by the natural variability of this species; some of those are typical of epigean species whose hypogean population is in status nascendi. Agonistic behavior for this species has been reported (Romero op. cit.). The definite taxonomy of this species has yet to be clarified. Part of the problem is the poor knowledge on the systematics of the genus Trichomycterus in general. Although morphological differences have been used to suggest specific differentiation between the hypogean population and the epigean one in nearby waters (Andreani Armas op. cit., Galán 1995), such contention is not supported by genetic studies (Pérez \& Moodie 1993).

55. Trichomycterus itacarambiensis Trajano \& de Pinna, 1996. Common name: None given. Etymology: itacarambiensis (L) after the name of the county, Itaracambi, in the state of Minas de Gerais, where it was found. Major synonyms: None. History: Although specimens of this fish had been collected since 1984 and even papers published about it (Carvalho \& de Pinna 1986), it was not formally described until 1996. Distribution: Brazil, Minas Gerais state, Município (county) de Itacarambi, creek inside Olhos d'Agua Cave (15 $\left.06^{\circ} 06^{\prime \prime} \mathrm{S}, 44^{\circ} 09^{\prime} 30^{\prime \prime} \mathrm{W}\right)$. Habitat and ecology: Found throughout most of the cave. Generally, depigmented individuals increase in number as one goes farther into the cave. The estimated population size is between 1500 and 2000 (Trajano 1997b). This fish feeds mostly on living animals such as small arthropods and oligochaetes (Trajano 1997a). Remarks: This population consists of both depigmented and pigmented individuals with variable eye size and variable pigmentation.

Family: Loricariidae

This is a large family (ca. 550 species) of freshwater fishes from Costa Rica, Panama and South America. Their body lacks true scales but is generally covered by bony plates. Their mouth is ventral, with or without conspicuous barbels. They are usually found in swift-flowing streams from lowlands up to $3000 \mathrm{~m}$ a.s.l. They tend to be detritivorous (Nelson 1994). No remarkable characteristic seems to make fish of this family preadapted to the hypogean environment. The genus Ancistrus has 60 species, three of which are hypogean.

56. Ancistrus cryptophthalmus Reis, 1987. Common name: None given. Etymology: cryptos (Gr) hidden, covered, concealed; ophthalmos (Gr) eye. Major synonyms: None. History: This fish was known since at least 1972 when a specimen was collected, possibly by Rene Ginet, but then lost. The first specimens in museum collections today are paratypes collected by E. Ferrari and Claude Vidal in 1972. The holotype was collected in 1980 by a group of the Clube Alpino Paulita. Distribution: Brazil, Goiás state, Sao Domingos, Rio Sao Vicente system, Caverna Passa 
Três, ca. $300 \mathrm{~m}$ into the cave $\left(13^{\circ} 20^{\prime}\right.$ to $13^{\circ} 52^{\prime} \mathrm{S}, 46^{\circ} 16^{\prime}$ to $\left.46^{\circ} 30^{\prime} \mathrm{W}\right)$. Habitat and ecology: It is a bottomdweller with a strong preference for rocky substrates in fast-flowing stream sectors. It is found in relatively high population densities (Trajano 2001b). Remarks: It coexists with a Trichomycterus sp. and Astyanax sp. Eyes in different degrees of reduction, sometime sunken under the skin. Small specimens have externally visible eyes which are reduced in size and become completely covered by dermal ossifications and skin during growth. Body almost entirely depigmented.

57. Ancistrus formoso Sabino \& Trajano, 1997. Common name: None given. Etymology: formoso (L) after the type locality, Rio Formoso. Major synonyms: None. History: The first specimen was collected in 1995 and the second in 1996. Distribution: Brazil, Mato Grosso do Sul state, Município (county) de Bonito, Serra da Bodoquena, Buraco do Ducho cave $\left(21^{\circ} 08^{\prime} \mathrm{S}, 56^{\circ} 28^{\prime} \mathrm{W}\right)$. Habitat and ecology: It is found in resurgences of caves of difficult access. Remarks: Reduced eyes not externally visible. It is totally depigmented. Abdomen naked.

\section{Ancistrus galani Perez \& Viloria, 1994. Common} name: None given. Etymology: galani (L) after Carlos Galán who collected the holotype. Major synonyms: None. History: The holotype and the paratype were collected on 10 March 1990 and 25 March 1991, respectively. Distribution: Venezuela, Zulia state, Sierra de Perijá, Río Socuy, Cueva de Los Laureles $\left(10^{\circ} 45^{\prime} 04^{\prime \prime} \mathrm{N}, 72^{\circ} 27^{\prime} 42^{\prime \prime} \mathrm{W}\right)$. Habitat and ecology: This cave is inhabited by a number of common epigean fishes, including Ancistrus brevifilis bodenhameri, none of which show true troglomorphic characters. A. galani is found only in remote gallery of the cave. Remarks: Reduced eyes and pigmentation. Description made based on only two specimens.

Family: Astroblepidae

This is a family of about 40 species of freshwater fishes found in the Andean region (South America) and Panama. Astroblepids have two pairs of barbels. They are characterized by their naked body and the presence of a mouth disc which allows some of them to climb the faces of waterfalls of torrental mountain streams. They also have maxillary and nasal barbels (Nelson 1994). These could be considered preadapted characters. There are two hypogean species within the genus
Astroblepus. The vague reference to the Colombian Astroblepus cyclopus (originally described as Pimelodus cyclopum) by Humboldt (1805) as a cave fish cannot be substantiated (Romero \& Paulson 2001).

59. Astroblepus pholeter Collette, 1962. Common name: None given. Etymology: pholeter $(\mathrm{Gr})$ means 'one who lurks in hole'. Major synonyms: None. History: Collected in 1961 and 1962 by Pedro I. Porras who sent the specimens to the U.S. National Museum. Distribution: Ecuador, Napo province, Jumandi Cave in Latas, $4 \mathrm{~km}$ north of Archidona $\left(0^{\circ} 20^{\prime}-0^{\circ} 40^{\prime} \mathrm{S}\right.$, $77^{\circ} 50^{\prime} \mathrm{W}$ ). Habitat and ecology: Found between 300 and $2000 \mathrm{~m}$ from the entrance of the cave. Hides in holes of rocks. Insect remains have been found in the stomachs of captured specimens. Remarks: Microphthalmic and slightly depigmented. It has a reduced swimbladder (Chardon 1966). Precise relationship to other members of the genus Astroblepus has yet to be established.

60. Astroblepus riberae Cardona \& Guerao, 1994 Common name: None given. Etymology: riberae (L) after C. Ribera, the collector of the first specimens. Major synonyms: None. History: Collected on 20 August 1977 by Ribera. Distribution: Peru, Cajamarca region, Río Reque basin, Pacific drainage, Grutas (caves) de Ninabamba $\left(6^{\circ} 19^{\prime} 48^{\prime \prime} \mathrm{S}, 78^{\circ} 30^{\prime} 36^{\prime \prime} \mathrm{W}\right)$. Habitat and ecology: No information available Remarks: Vestigial eyes under the skin. Depigmented. Scaleless. Precise relationship with other members of the genus Astroblepus has yet to be established.

\section{Family: Sternopygidae}

This is a family made up of 15 species found in the freshwaters of South America. They have an elongated, compressed body. Like other members of the order Gymnotiformes, they posses electric organs that are the result of transformed muscles. They use these organs to search for food, obstacles, other fishes (electrogenic or not) and for defense. They are mainly nocturnal fishes many of which are found only in the deep waters of major rivers of the Amazon basin (Nelson 1994). These characters could be considered preadaptations to the hypogean environment. Only one hypogean species has been described so far.

61. Eigenmannia vicentespelaea Triques, 1996 Common name: None given. Etymology: vicente (L) 
from the name of the cave; spelaea (L) cave. Major synonyms: None. History: First collected by P. Slavec in July 1978. Distribution: Brazil, Goiás state, Rio Sao Vicente system, Rio Tocantins basin, at Sao Domingos, Gruta (cave) Sao Vicente II $\left(13^{\circ} 35^{\prime} 00^{\prime \prime} \mathrm{S}\right.$, $46^{\circ} 22^{\prime} 30^{\prime \prime} \mathrm{W}$ ). Habitat and ecology: No information available. Remarks: The main difference between this species and other members of the same genus is its reduced eyes which are covered by thick skin. It is somewhat depigmented. The body is covered by uniformly cycloid scales whose size decreases from lateral line to dorsal and ventral regions. Scales in the dorsal and ventral regions are two or three times smaller in diameter than those near the lateral line. It is not known whether this fish utilizes its electric organs in the hypogean environment. Even if this was the case, and despite its obvious usefulness in this habitat, this cannot be considered a phylogenetic novelty since this is a character shared by all members of the order Gymnotiformes.

Family: Amblyopsidae

This is a family of freshwater fishes found in the southern and eastern United States. It is composed of six species, four of which are clearly troglomorphic; one is a trogloxene (facultative cavernicole) and one is found in swamps. Scales are cycloid but head is naked. Eyes range from small to vestigial. They have rows of sensory papillae on the head, body, and tail (Nelson 1994). The fact that the only epigean species of the family lives in dark swamp waters, one is a facultative cavernicole, and the other four are troglomorphic species makes this family the archetypical hypogean fish group.

62. Amblyopsis rosae (Eigenmann, 1897). Common name: Ozark cavefish (E). Etymology: rosae (L) after C.H. Eigenmann's wife and ichthyologist Rosa Smith. Major synonyms: Typhlichthys rosae, original description; Troglichthys rosae (Eigenmann, 1899). History: First reported from specimens collected from caves near Sarcoxie, Missuori by Garman (1889) as Typhlichthys subterraneus. The description was first published by Eigenmann (1897) with brief characterization involving eyes, and then described in more detail in Eigenmann (1898). Distribution: U.S.A., it is presently known from 41 caves in the Ozark Plateau, distributed over seven counties in three states, northwestern Arkansas, northeastern Oklahoma, and in the southern corner of Missouri (ca. $36^{\circ} 53^{\prime} \mathrm{N}, 95^{\circ} 03^{\prime} \mathrm{W}$ ).
The verified historic range was larger (Romero 1998a). Habitat and ecology: Found mostly in small cave streams with chert or rubble bottom. Also occasionally found in pools over silt and sand bottom. Stomachs examined contained copepods which constituted about $70-90 \%$ by volume with the balance being primarily small salamanders, crayfish, isopods, amphipods and young of their own species (Poulson 1963). Remarks: Rudimentary eyes hidden under the skin. Depigmented body with few nonfunctional pigmented cells. It is a very old and highly genetically distinct clade of amblyopsid fishes. It has been proposed that there are two subspecies of this fish: A. rosae whitae for the White River drainage and A. rosae arkansasus for the Middle Arkansas River drainage (Romero op. cit.).

63. Amblyopsis spelaea DeKay, 1842. Common name: northern cavefish (E). Etymology: amblus (Gr) blunt, point taken off; ops (Gr) eyes; spelaea (L) cave. Major synonyms: Originally described as Amblyopsis spelaeus. History: This was the first troglobitic species of fish ever described in the scientific literature. Distribution: U.S.A., in about 2500 caves in Kentucky and about 1800 caves in southern Indiana (ca. $37^{\circ}-39^{\circ} \mathrm{N}, 85^{\circ}-87^{\circ} \mathrm{W}$ ). Its distribution may be limited by competition with another amblyopsid cavefish, Typhlichthys subterraneus. Habitat and ecology: Found only in caves and subterranean passages of welldeveloped karst terrain whose water comes from the precipitation diverted underground through sinkholes and sinking streams. It is most often found in caves with uniform silt-sand substrates. It is a top predator (Romero \& Bennis 1998). Remarks: Rudimentary eyes hidden under the skin. Body depigmented with non-functional pigment cells. It has small cycloid scales. It has a well-defined annual cycle: breeding occurs during high water from February to April, the females carry the eggs in their gill cavities until hatching and carry the young until their lose their yolksacs, a total period of 4-5 months, then the young appear in late summer and early fall. Low reproductive rate. It is scotophilic (Green \& Romero 1997).

64. Chologaster agassizii Putnam, 1872. Common name: spring cavefish (E). Etymology: aggassizzi (L) after Louis Agassiz who allowed Putnam to study the specimens. Major synonyms: Forbesella agassizi (Page \& Burr, 1991), Forbesichthys agassizi (Boschung, 1992, Etnier \& Starnes, 1993). 
Preoccupied by Forbesella in tunicates, replaced by Forbesichthys Jordan, 1929. History: First collected in a well in Lebanon. Tennessee, and presented to the Museum of Comparative Zoology at Harvard, by J.M. Safford in January 1854. Distribution: U.S.A., central and western Kentucky (west to Tennessee River) to southern central Tennessee; west across southern Illinois to southeastern Missouri (ca. $\left.35^{\circ} 00^{\prime}-37^{\circ} 30^{\prime} \mathrm{N}, 86^{\circ}-92^{\circ} \mathrm{W}\right)$. Habitat and ecology: Occurs in springs and caves (but almost always near surface). Lives underground but emerges above ground in springs (Page \& Burr op. cit.). Remarks: Active in springs at night and usually retreats underground during the day. The few individuals which venture into the spring portions of their habitat may show strong rheotaxis for half to one-minute periods but usually show strong thigmotaxis and hide under rocks or debris (Poulson 1963). Feeds at night on amphipods, midge larvae, tiny worms and microcrustaceans. Fecundity averages about 100 eggs per female (Etnier \& Starnes op. cit.).

65. Speoplatyrhinus poulsoni Cooper \& Kuehne, 1974. Common name: Alabama cavefish (E). Etymology: speos $(\mathrm{Gr})$ cave; platys (Gr) flat; rhinus (Gr) nose, referring to the greatly flattened snout; poulsoni (L) after American cave fish researcher T.L. Poulson. Major synonyms: None. History: Captured by J.E. Cooper and his spouse on 19 March 1967 while collecting crayfish in Kay Cave, Alabama. Distribution: U.S.A., Alabama, apparently restricted to Key Cave, Lauderdale county, in the north bank of the Tennessee River. Habitat and ecology: The habitat is mostly lacustrine (lentic, phreatic groundwater) (for more details see Romero 1998c). Population is estimateed to be no more than 100 individuals, which would made of this one the most endangered fish species in the world. Remarks: No externally visible eyes. Body depigmented with few scattered nonfunctional melanophores. Body covered by embedded cycloid scales.

66. Typhlichthys subterraneus Girard, 1859. Common name: southern cavefish (E). Etymology: typhlops (Gr) blind, ichthys for iktus (Gr) fish; subterraneus (L) underground. Major synonyms: Typhlichthys wyandotte (Eigenmann, 1905), T. osborni (Eigenmann, 1905), T. eigenmanni (Hubbs, 1938). History: The first specimen was taken from a well near
Bowling Green, Warren Co., Kentucky, and sent to the Smithsonian Institution by J.E. Younglove. Distribution: U.S.A., subterranean waters in two major disjunct ranges being separated by the Mississippi River, Ozark Plateau of central and southeastern Missouri and northeastern Arkansas, and Cumberland and Interior Low plateaus of northwest Alabama, northwest Georgia, central Tennessee and Kentucky and southern Indiana (ca. $37^{\circ} 00^{\prime} \mathrm{N}, 86^{\circ} 29^{\prime} \mathrm{W}$ ). Habitat and ecology: Mostly lentic but also in pools of streams at or near water table (for more details see Romero 1998b). Remarks: Rudimentary eyes hidden under the skin. Body depigmented with few non-functional pigment cells. Scales minute and embedded. It does not respond to light (Green \& Romero 1997).

Family: Bythitidae

This is a family composed of about 90 species of mostly marine fishes with a few representatives living in brackish and fresh waters. Their distribution includes the Atlantic, Indian, and Pacific Oceans. They usually have scales and the swimbladder is present. Their opercles usually have a strong spine. All members of this family are viviparous (Nelson 1994). They have no characters that can be labeled as preadaptaed to the hypogean environment, yet seven species belonging to two genera of the family are hypogean. Of the six species of Lucifuga, five are hypogean. Lucifuga is divided into two subgenera; the difference between the two is that Lucifuga (Lucifuga) has palatine bones but without teeth with pectoral fin rays numbering $12-14$, usually 12-13, while Lucifuga (Stygicola) has palatine teeth and pectoral fin rays numbering $15-20$. The species of this genus need to be studied using genetic techniques. Given that some of these species can be found together as well as the large overlap of characters among them, it raises questions of whether they represent just populations of no more than two species. Hybridizations may also occur. Until these species are studied from a population genetics perspective, rather than purely morphological, we will not know for sure. Of the five species of Ogilbia, two are hypogean.

67. Lucifuga (Lucifuga) subterraneus Poey, 1858. Common name: Cuban cusk-eel (E). Etymology: fugere lucem (L) because it is photophobic; subterraneus (L) underground. Major synonyms: None. History: The first person to report this fish was Tranquilino Sandalio de Noda in 1831, which predates the first reports of Amblyopsis spelaea. Through him and 
others, Poey secured the specimens he used in his first published description (Romero 2001). Distribution: Cuba, in several anchialine caves of the Pinar del Rio and Habana provinces (ca. $21^{\circ} 50^{\prime} \mathrm{N}, 84^{\circ} 57^{\prime} \mathrm{W}$ ). Habitat and ecology: In caves and sink-holes formed by solution of underlying limestone. Frequently found syntopically with $L$. dentatus. It can tolerate brackish waters. It feeds on cirolanid isopods. Remarks: Eyes poorly developed and not externally visible in many preserved specimens. Yellowish-white pigmentation. The body is covered with small, imbricate scales.

68. Lucifuga (Lucifuga) teresinarum Díaz Perez, 1988. Common name: None given. Etymology: teresinarum (L) after Maria Teresa del Valley Portilla and Maria Teresita de la Hoz Gonzalez, both faculty at the Universidad de la Habana. Major synonyms: None. History: Both the holotype and the paratype were captured on 20 October 1986 by A. Montoto Lima and E. García Machado, both skin divers. Distribution: Cuba, Habana province, Cuevas de Ashton (Cueva de la Lechuza and Cueva Baño II), Barrios de las Cañas Artemisa (ca. $22^{\circ} 50^{\prime} \mathrm{N}, 82^{\circ} 40^{\prime} \mathrm{W}$ ). Habitat and ecology: In the Cueva de la Lechuga it is found with isopods and introduced guppies. In the Cueva Baño II is found with $L$. subterraneus and $L$. dentatus as well as several species of crustaceans. This fish species is prey of crustaceans, Epilobocera sp. Remarks: Eyes not visible externally. Depigmented. Cycloid scales on parts of the body. It has a number of characteristics that place it as a composite of $L$. (L.) subterraneus (upper profile of the head, lack of palatine teeth, number of pectoral rays) and $L$. (S.) dentatus (free caudal fin and male intromitent organ).

69. Lucifuga (Stygicola) dentatus Poey, 1858. Common name: toothed Cuban cusk-eel (E). Etymology: dentatus (L) with teeth. Major synonyms: Stygicola dentatus (original description). History: Same as for $L$. (L.) subterraneus. Distribution: Same as for $L$. (L.) subterraneus (ca. $21^{\circ} 50^{\prime} \mathrm{N}, 84^{\circ} 57^{\prime} \mathrm{W}$ ). Habitat and ecology: Same as for L. subterraneus. Found syntopically with $L$. (L.) subterraneus and $L$. (L.) teresinarum. Feeds on cirolanid isopods. Remarks: Eyes not externally visible. Depigmented. Viviparous.

70. Lucifuga (Stygicola) simile Nalbant, 1981. Common name: None given. Etymology: simile (L) because of its intermediate features between $L$. subterraneus and $L$. dentatus. Major synonyms: None.
History: Collected by C. Jubertie on 7 November 1970. Distribution: Cuba, Matanzas province, Grieta Punta de Guana, ca. $100 \mathrm{~m}$ from shoreline of Atlantic Ocean (ca. $23^{\circ} 04^{\prime} \mathrm{N}, 81^{\circ} 35^{\prime} \mathrm{W}$ ). Habitat and ecology: Found in a sinkhole near the ocean. The only stomach contents reported so far for this species have been plant remains. Remarks: Completely depigmented, 57-60 anal rays. This species has palatine teeth as the other representatives of the subgenus Stygicola, but at the same time its caudal fin is confluent with both dorsal and anal fins, which is unique to L. subterraneus.

71. Lucifuga (Stygicola) spelaeotes Cohen \& Robins, 1970. Common name: New Providence cusk-eel (E). Etymology: spelaeotes (Gr) cave dweller. Major synonyms: None. History: The first specimens were collected by Carleton Ray on 24 October 1967. Distribution: Bahamas, New Providence Island, Mermaid's Pool, SW Nassau (ca. $25^{\circ} 05^{\prime} \mathrm{N}, 77^{\circ} 20^{\prime}$ W). Habitat and ecology: This fish lives in anchialine caves (Iliffe 1992) on several Bahamian Islands. Some of them (e.g., Mermaids Hole, Uncle Charlie's Blue Hole) are typical inland holes of the cenote type, circular openings between 30 and $250 \mathrm{~m}$ across and from 2 to $110 \mathrm{~m}$ depth. Remarks: Eyes not very well developed and small. The entire body is covered by small, rounded imbricate scales. It has more coloration than $L$. dentatus and seems more primitive than $L$. dentatus.

72. Ogilbia galapagosensis (Poll \& LeLeup, 1965). Common name: Galapagos cuskeel (E). Etymology: galapagosensis (L) because it is found in the Galápagos Islands. Major synonyms: Caecogilbia galapagosensis (original description). History: Collected on 4 December 1964 by A. De Roy and N. Leleup. Distribution: Chile, Galápagos Archipelago, Santa Cruz Island (ca. $1^{\circ} 00^{\prime} \mathrm{S}, 90^{\circ} 55^{\prime} \mathrm{W}$ ). Habitat and ecology: In crevices of a lagoon. Rare and difficult to observe (Illife 1991). Remarks: Eyes and pigmentation reduced and variable. However, in the pictures of this fish (Allen \& Robertson 1994) examined by us there is no noticeable difference between $O$. galapagosensis and other species of the same genus living in the same area. It has small scales. Hardly a 'cave' fish, despite the fact that it is usually listed as such.

73. Ogilbia pearsei (Hubbs, 1938). Common name: Dama ciega blanca (S). Etymology: pearsei (L) after A.S. Pearse who collected the first specimens. Major synonyms: Typhlias pearsei (original description), 
Typhliasina pearsi (e.g., Wilkens 1973, ChumbaSegura 1983). History: Collected by Pearse on 22 June 1936. Distribution: Mexico, Yucatán peninsula (see Chumba-Segura 1983 for distributional map) (ca. $\left.20^{\circ} 40^{\prime} \mathrm{N}, 88^{\circ} 32^{\prime} \mathrm{W}\right)$. Habitat and ecology: Stable environments, clear waters. Does not seem to be very abundant (Chumba-Segura op. cit). Remarks: Eyes and pigmentation variable. Small scales covering only parts of the body. Sex ratio may be skewed towards females.

\section{Family: Poecilidae}

This family is represented by about 300 species of freshwater and brackish water fish found from eastern United States to South America and in Africa, including Madagascar (Nelson 1994). No characters that could be assigned as preadapted. Only one hypogean species.

74. Poecilia mexicana Steindachner, 1863. Common name: cave shortfin molly (E). Etymology: Not applicable. Major synonyms: Poecilia sphenops (Valenciennes, 1846), Mollienisia sphenops (Regan, 1913), Mollienisia mexicana (Hubbs, 1961). History: The first cave population was described by Gordon \& Rosen (1962). Distribution: Mexico, Estado de Tabasco, Cueva de las Sardinas, near Tapijulapa Village, about $26 \mathrm{~km}$ south of Teapa (ca. $18^{\circ} 51^{\prime} \mathrm{N}$, $\left.97^{\circ} 08^{\prime} \mathrm{W}\right)$. Habitat and ecology: The environment is a calcium sulfate stream. Remarks: There is a lot of variation in the troglomorphic characters: the deeper you go into the cave, the more the eyes are reduced in size and the lower the pigmentation, while there is an increase in the thickness of the lips of the mouths (Parzefal 2001)

\section{Family: Synbranchidae}

This family is made up of about 17 species of freshwater and occasionally brackish water fishes. Found in tropical and subtropical waters in Asia, Indo-Australian Archipelago, West Africa (Liberia), Mexico, Central and South America. They are eellike fishes with no pectoral or pelvic fins; rudimentary dorsal and anal fins; and a caudal fin that is small or rudimentary, or lacking altogether. Scales are absent or confined to the caudal region. They have small eyes and lack swimbladders or ribs. Mostly air breathers. Many are burrowers (Nelson 1994). All these characters can be considered preadaptive to the hypogean environment.
There are two genera with two species each that are hypogean. Ophisternon is a genus of six species of circumtropical distribution with a disjunct distribution of species; they all lack scales. Monopterus is an Old World genus represented by seven species that also lack scales; two of those species are hypogean. The contention by Galán $(1982,1995)$ that M. boueti was found in caves is erroneous. Given the geographic proximity of the two hypogean species of Monopterus, it would be interesting to investigate the genetic relationships between both as well with their putative ancestor M. albus. A depigmented individual of Synbranchus marmoratus was collected in a cave in northeastern Venezuela in 1979 (Galán 1982), but this fish recovered its pigmentation when exposed to light. Further studies in this locality are needed in order to confirm the troglomorphic nature of this potential hypogean population.

75. Monopterus (Monopterus) eapeni Talwar in Talwar \& Jhingran, 1991. Common name: Malabar swampeel (E). Etymology: eapeni (L) after K.C. Eapen, who first described the species under a preoccupied name. Major synonyms: Monopterus indicus (Eapen, 1963). Secondarily preoccupied in Monopterus by Amphipnous indicus Silas \& Dawson, 1961, replaced by Monopterus eapeni Talwar, 1991. History: No information available. Distribution: India, Kerala state, well at Kottayam $\left(9^{\circ} 30^{\prime} \mathrm{N}, 76^{\circ} 33^{\prime} \mathrm{E}\right)$. Habitat and ecology: No information available except that another troglomorphic fish, Horaglanis krishnai, is found in the same well. Remarks: Sunken eyes. Scaleless. It may have derived from M. albus.

76. Monopterus roseni Bailey \& Gans, 1998. Common name: None given. Etymology: roseni (L) after Donn E. Rosen, an American ichthyologist. Major synonyms: None. History: Collected in July 1986 by Carl Gans, S.K. Saraswat and C. Rajasunderam. Distribution: India, Kerala state, from a well, Periyam village $\left(10^{\prime} 38^{\prime} \mathrm{N}, 76^{\circ} 22^{\prime} \mathrm{E}\right)$. This location is about $102 \mathrm{~km}$ slightly west of north from Kottayam, the type locality of $M$. eapeni. Habitat and ecology: Collected in the village water supply, $50 \mathrm{~m}$ a.s.l. Remarks: Blind. Depigmented. Scaleless. The non-troglomorphic differences between these two species are mostly in body proportions and number of vertebrae.

77. Ophisternon candidum (Mees, 1962). Common name: blind cave eel (E). Etymology: candidum (L) 
whitish, for the pale appearance of the skin. Major synonyms: Anommatophasma candidum (original description). History: First observed by Alf Snell who mentioned the existence of a 'blind eel' sometime in 1959, and in that year A.N. Douglas and G.F. Mees collected the fist specimen. Distribution: Australia, western and northeastern coastal plain of the Cape Range peninsula. Found in 11 locations (two now destroyed) in numbers ranging from one to three individuals (for a distributional map see Humphreys 1999) (ca. $22^{\circ} 07^{\prime} \mathrm{S}, 113^{\circ} 57^{\prime} \mathrm{E}$ ). Habitat and ecology: In wells, sinkholes, and caves, and possibly in groundwater. This species feeds on invertebrates, both hypogean and epigean, that accidentally fall into their habitat (Humphreys \& Feinberg 1995). Remarks: No externally visible eyes. Whitish coloration in the skin (Romero \& Vanselow 2000b). Scaleless. It may have derived from Synbranchus bengalensis, the only other synbranchid known to occur in Western Australia.

78. Ophisternon infernale (Hubbs, 1938). Common name: blind swamp eel (E), anguila ciega de los cenotes (S). Etymology: infernale (L) from hell (Hubbs liked to name cave fishes with diabolic names based on the idea of hell being underground; see etymology for Satan eurystomus). Major synonyms: Pluto infernalis (original description); Furmastix infernalis (Whitley, 1951b); Synbranchus infernalis (Mees, 1962). History: The holotype was collected by A.S. Pearse on 7 July 1936. Distribution: Mexico, in the cenotes of central and northern Yucatan peninsula (see Chumba-Segura 1984 for distributional map) (ca. $20^{\circ} 40^{\prime} \mathrm{N}, 88^{\circ} 30^{\prime} \mathrm{W}$ ). Habitat and ecology: Found in shallow waters of sinkholes with sediments that are nutrient-rich. Remarks: No externally visible eyes. Depigmented. Scaleless. Most likely is derived from Synbranchus marmoratus.

\section{Family: Eleotridae}

This is a family of mostly tropical and subtropical fishes, both marine and freshwater, represented by about 150 species (Nelson 1994). No particular characteristics that could be seen as preadapted.

79. Milyeringa veritas Whitley, 1945. Common name: blind cave gudgeon (E). Etymology: Milyeringa $(\mathrm{L})$ after Milyering, Yardie, Western Australia, the type locality; veritas (L) true, 'because, like Truth, it was found at the bottom of a well' (Whitley 1951a). Major synonyms: None. History: The first twelve specimens were collected from a freshwater well by its owner, Eric Payne, on 18 October 1944. It is believed that the existence of this fish was known by the locals since the 1920's. Distribution: Australia, western and northeastern coastal plain of the Cape Range peninsula and Barrow Island. Found in 19 locations (now absent from two) in numbers of up to more than 100 individuals (Humphreys 2001) (ca. $22^{\circ} 00^{\prime} \mathrm{S}, 114^{\circ} 00^{\prime} \mathrm{E}$ ). Habitat and ecology: In wells, sinkholes, caves, and bores and probably widely in the anchialine and fresh groundwater. It is sympatric with Ophisternon candidum but seems much more abundant. Remarks: Eyes not externally visible. Whitish coloration in the skin. Scales are reduced and entirely absent from the head; there are about 28 rows in a longitudinal line. $M$. veritas closest affinity is possibly with the eleotrid genus Butis, a mangrove dwelling genus of brackish and freshwaters on the Indo-Australian Archipelago (Romero \& Vanselow 2000a).

80. Oxyeleotris caeca Allen, 1996. Common name: ihaaribi (blind, in Yagi language). Etymology: caeca (L) blind. Major synonyms: None. History: Rumors of the existence of this fish date back to 1978 but it was not captured until June 1995 by inhabitants of Kafa Village. Distribution: Papua New Guinea, creek near Kafa, tributary of the Mubi River, upper Kikori River system (ca. $6^{\circ} 34^{\prime} 30^{\prime \prime}{ }^{\circ} \mathrm{S}, 143^{\circ} 29^{\prime} 30^{\prime \prime}$.E). Habitat and ecology: In a creek connected to a small cave $100-200 \mathrm{~m}$ upstream, at an elevation of $650 \mathrm{~m}$ a.s. 1 . Remarks: Eyes not externally visible. Mostly depigmented except for the dorsal region. Most of the scales embedded. Description based on a single specimen. Seems to be closely related to $O$. fimbriata, one of the most widely distributed gudgeons in New Guinea and the only freshwater-restricted member of the genus occurring on both sides of the Central Dividing Range.

81. Typhleotris madagascariensis Petit, 1933. Common name: toho (in Mihafale). Etymology: typhlos (Gr) blind; eleotris (L) because of its relation to the genus Eleotris; madagascariensis (L) after the island where it was found. Major synonyms: None. History: Collected by H. Perrier de la Bàthie at an unspecified date. Distribution: Madagascar, province of Toliara: south of Onilahy River, at Mitoho caves, underground waters in Mahafaly, ca. $1 \mathrm{~km}$ north of the natural reserve of Lake Tsimanampetsotsa (ca. $24^{\circ} 08^{\prime} \mathrm{S}, 43^{\circ} 48^{\prime} \mathrm{E}$ ). Habitat and ecology: In underground lakes below 
what is now a desert where it feeds on crustaceans and insects. Remarks: Sunken eyes. Variable levels of depigmentation (Angel 1949). Degenerated ctenoid scales (Poisson \& Besairie 1947).

82. Typhleotris pauliani Arnoult, 1959. Common name: None given. Etymology: pauliani (L) after R. Pauliani who secured the first specimens. Major synonyms: None. History: Pauliani collected the first specimens in July 1956. Distribution: Madagascar, Andalambezo region near Morombe, north of Onilahy River (ca. $23^{\circ} 00^{\prime} \mathrm{S}, 44^{\circ} 30^{\prime} \mathrm{E}$ ). Habitat and ecology: In underground lakes below what is now a desert where it feeds on bat guano and aquatic insects. Remarks: No externally visible eyes. Depigmented. Irregular (degenerated?) scales that sometimes look cycloid, sometimes ctenoid

\section{Family: Gobiidae}

This is a very large family (possibly $>2000 \mathrm{spp}$.) of mostly marine and brackish species. Mostly of small size, they tend to be cryptic bottom dwelling carnivores feeding on small benthic invertebrates. Very common in fresh waters on oceanic islands (Nelson 1994). Thus, it is not surprising that all four hypogean species described thus far are from islands: two from Japan, one from the Phillippines and one from Madagascar.

The two species of Luciogobius seem to be valid based on the differences in their meristic, nontroglomorphic differences and allopatry; both of them most probably descended from Luciogobius guttatus. The third species also seems to be valid: the monotypic genus Caecogobius does not appear to be related to any other extant species. More information is needed regarding the fourth, Glossogobius ankaranensis, given the fact that it has been found syntopically with the congeneric Glossogobius callidus.

83. Caecogobius cryptophthalmus Berti \& Ercolini, 1991. Common name: None given. Etymology: caeco (L) blind; gobius (L) for its relationship to species of the genus Gobius; crypto (L) hidden; ophthalmus (L) eyes. Major synonyms: None. History: The first four specimens were collected by members of the Federazione Speleologica Veneta in January and February 1987. Distribution: Philippines, Samar Island, Calbiga Cave system $\left(12^{\circ} 00^{\prime} \mathrm{N}, 125^{\circ} 00^{\prime} \mathrm{E}\right)$ Habitat and ecology: No information available. Remarks: No externally visible eyes. Strongly reduced pigmentation. Phylogenetic relationships are unknown.

84. Glossogobius ankaranensis Banister, 1994. Common name: None given. Etymology: ankaranensis (L) after the region of Ankarana where this fish was first collected. Major synonyms: Gobius ankaranensis (Wilson, 1996). History: First collected by Jane Wilson and her colleagues in 1986. Distribution: Madagascar, Ankarana reserve in a subterranean river (see Wilson op. cit. for a map of the area) (ca. $\left.12^{\circ} 50^{\prime} \mathrm{S}, 49^{\circ} 10^{\prime} \mathrm{E}\right)$. Habitat and ecology: In a cave where they feed on blind and eyed shrimps. They may also feed on insects and bat guano. It is found syntopically with eyed Glossogobius callidus. Remarks: Eyes reduced to small spots. Body depigmented. Thin and weak ctenoid scales.

85. Luciogobius albus Regan, 1940. Common name: dôkutsu-mimizuhaze (J), cave earthworm goby (E). Etymology: albus (L) white, referring to the color of the skin. Major synonyms: None. History: First reported by Masatoshi Iwata in 1934 (Torii 1951). Based on two specimens of Luciogobius guttatus guttatus of Tomiyama (1936, p. 51, figure 10C). Distribution: Asia, Japan, Prefectures of Wakayama, Kochi, Shimane, Nagasaki and the Gotô islånds (Masuda ẹt al. 1984). Originally collected in the cave of Daikon-zima in Simani-ken (ca. $32^{\circ}-36^{\circ} \mathrm{N}, 128^{\circ}-136^{\circ} \mathrm{E}$; but not throughout the entire square defined by these coordinates). Habitat and ecology: Inhabits underground waters near the sea. Remarks: Vestigial eyes. Depigmented (pinkish due to the color of the blood). Like L. pallidus, it lacks free rays on the pectoral fin.

86. Luciogobius pallidus Regan, 1940. Common name: ido-mimizuhaze $(\mathrm{J})$, well earthworm goby $(\mathrm{E})$. Etymology: pallidus (L) for pale referring to the color of the skin. Major synonyms: None. History: First reported by Masatoshi Iwata in 1934 (Torii 1951). Based on artesian well specimens of Luciogobius guttatus guttatus of Tomiyama (1936, p. 51, figure 10D). Distribution: Asia, Japan, prefectures of Mie, Wakayama, Kochi, Ehime, Kumamoto, and Yamaguchi (Masuda et al 1984, Uéno \& Morimoto 1970). Original specimens collected from an artesian well (ca. $32^{\circ}-36^{\circ} \mathrm{N}, 128^{\circ}-136^{\circ} \mathrm{E}$; but not throughout the entire square defined by these coordinates). Habitat and ecology: Inhabits underground waters near 
the sea. Remarks: Reduced, sunken eyes. Slightly depigmented. Like $L$. albus, it lacks free rays on the pectoral fin.

\section{Acknowledgements}

Jerry Reedy helped with the etymologies. Giang Ho helped with the translation of literature in Vietnamese Qin Zheng and Janet Ebaugh were helpful translating texts from Chinese. Carol Gersmehl and the Macalester College Cartography Laboratory assisted with the maps.

\section{References cited}

Allen, G.R. 1996. Oxyeleotris caeca, a new species of blind cave fish (Eleotridae) from Papua New Guinea. Rev. Fr. Aquariol. 23: $43-46$.

Allen, G.R. \& D.R. Robertson. 1994. Fishes of the tropical eastern Pacific. Crawford House Press, Bathurst. 332 pp.

Alvarez, J. 1946. Revisión del género Anoptichthys con descripción de una especie nueva (Pisc., Characidae). An. Esc. Nac. Cienc. Biol. Mex. 4: 263-282.

Alvarez, J. 1947. Descripción de Anoptichthys hubbsi caracínido ciego de la cueva de los Sabinos, S.L.P. Rev. Soc. Mex. Hist. Nat. 8: 215-219.

Andreani Armas, L.E. 1990. Estudio comparativo de dos poblaciones, una hipogea y otra epigea de Trichomycterus sp. (Siluriformes, Trichomycteridae). Bol. Soc. Venez. Speleol. (24): 7-11.

Andreas Buckup, P. 1988. The genus Heptapterus (Teleostei, Pimelodidae) in southern Brazil and Uruguay with the deseription of a new species. Copeia 1988: 641-653.

Angel, F. 1949. Contribution a l'etude du Typhleotris madagascariensis, poisson aveugle, cavernicole, du Sud-Ouest de Madagascar. Bull. Mus. Hist. Nat. Paris 21: 56-59.

Anonymous. 1981. Freshwater fishes of Guangxi. Fisheries Research Institute, Guangxi, Remnin Press, Nanking. 257 pp. (in Chinese)

Arnoult, J. 1959. Une nouvelle espèce de poisson aveugle de Madagascar: Typhleotris pauliani $\mathrm{n}$. $\mathrm{sp}$. Mem. Inst. Sci. Madagascar 13A: 133-138.

Avise, J.C. \& R.K. Selander. 1972. Evolutionary genetics of cavedwelling fishes of the genus Astyanax. Evol. 26: 1-19.

Bailey, R.M. \& C. Gans. 1998. Two new synbranchid fishes, Monopterus roseni from Peninsular India and $M$. desilvai from Sri Lanka. Occas. Pap. Mus. Zool. Univ. Mich. (726): 1-18.

Baird, S.F. \& C.F. Girard. 1854. Descriptions of new species of fishes collected in Texas, New Mexico and Sonora, by Mr. John H. Clark, on the U.S. and Mexican Boundary Survey, and in Texas by Capt. Stewart Van Vliet, U.S.A. Proc. Acad. Nat. Sci. Phil. 7: 24-29.

Banister, K.E. 1987. Two new species of Garra (TeleosteiCyprinidae) from the Arabian peninsula. Bull. Brit. Mus. Nat. Hist. 52: 59-70.
Banister K.E 1994. Glossogobius ankaranensis, a new species of blind cave goby from Madagascar (Pisces: Gobioidei Gobiidae). Aqua, J. Ichthy. Aquat. Biol. 1: 25-28.

Banister, K.E., J. Bell \& M. Crumpler. 1992. Omani blind cave fish. Aquarist and Pondkeeper 1992: 38-40.

Banister, K.E. \& M.K. Bunni. 1980. A new blind cyprinid fish from Iraq. Bull. Brit. Mus. Nat. Hist. (Zool.). 38: 151-158.

Berti, R. 1990. Specific chemical recognition in Phreatichthys andruzzii (Pisces, Cyprinidae). Mem. Biospeleol. 17: 31.

Berti, R. \& A. Ercolini. 1979. Aggressive behaviour in the anophthalmic phreatic fish Uegitglanis zammaranoi Gianferrari (Claridae, Siluriformes). Monit. Zool. Ital 13; 197.

Berti, R. \& A. Ercolini 1991. Caecogobius, cryptophthalmus n. gen. n. sp. (Gobiidae Gobiinae), the first stygobic fish from Philippines. Trop. Zool. 4: 129-138.

Berti, R. \& G. Thinès. 1980. Influence of chemical signals on the topographic orientation of the cave fish Caecobarbus geertsiBoulenger (Pisces, Cyprinidae). Experientia 36: 1384-1385.

Berti, R. \& L. Zorn. 2001. Locomotory responses of the cave cyprinid Phreatichthys andruzzii to chemical signals from conspecifics and related species: new findings. Env. Biol. Fish. 62: 107-1 14 (this volume).

Bianchi. S. 1975. Preliminary observations on the epidermis of Uegitglanis zammaranoi Gianferrari (Claridae: Siluriformes). Monit. Zool. Ital. 5: 91-101.

Bianchi, S., G. Delfino \& A. Ercolini. 1978. Morphology and structure of the olfactory organ in Uegitglanis zammarano Gianferrari (Claridae, Siluriformes), anophthalmic phreatic fish from Somalia. Monit. Zool. Ital. 10: 157-171

Biswas, J. 1991. Annual modulation of diel motor activity rhythm of the dusk active loach Nemacheils evezardi (Day). A correlation between day length and circadian parameters. Proc. Indian Nat. Acad. Sci. B57: 339-346.

Biswas, J., A.K. Pati, R.K. Pradhan \& R.S. Kanoje. 1990 Comparative aspects of reproductive phase dependent adjustments in behavioural circadian rhythms of epigean and hypogean fish. Comp. Physiol. Ecol. 15: 134-139.

Borodin, N.A. 1927. A new blind catfish from Brazil. Amer. Mus. Novit. (263): 1-5.

Boschung, H.T. 1992. Catalogue of freshwater and marine fishes of Alabama. Bull. Alabama Mus. Nat. Hist. (14): 1-266.

Boucquey, C., G. Thines \& C. Van Der Borght. 1965. Étude comparative de la capacité photopathique et de l'activité chez le poisson cavernicole Anoptichthys antrobius, chez la forme epigee ancestrale Astyanax mexicanus, et chez les hybrides $\mathrm{F}$ (Astyanax x Anoptichthys) et $\mathrm{F}_{2}$. pp. 79-103. In: J. Mendion (ed.) La Distribution Temporelle des Activités Animales et Humaines, Masson et Cie, Paris.

Boulenger, G. 1921. Description d'un poisson aveugle decouvert par M.G. Geerts dans la grotte de Thysville (Bas-Congo). Rev. Zool. Afr. 9: 252-253.

Breder, C.M. 1942. Descriptive ecology of La Cueva Chica, with especial reference to the blind fish, Anoptichthys. Zoologica 27: 7-15.

Breder, C.M. \& E.B. Gresser. 1941. Correlations between structural eye defects and behavior in the Mexican blind characin. Zoologica 26: 123-131.

Brittan, M.R. \& J.E. Böhlke. 1965. A new blind characid fish from southeaster Brazil. Notulae Naturae (380): 1-4. 
Brown, R.W. 1956. Composition of scientific words. Smithsonian Institution Press, Washington, D.C. 882 pp.

Bruton, M.N. 1995. Threatened fishes of the world: Clarias cavernicola Trewavas, 1936 (Clariidae). Env. Biol. Fish. 43: 162.

Bruun, A.F. \& E.W. Kaiser. 1944. Iranocypris typhlops, the firs true cave fish from Asia. Danish Scient. Invest. Iran (4): 1-8.

Burr, B.M., G.L. Adams, J.K. Krejca, R.J. Paul \& M.L. Warren, Jr. 2001. Troglomorphic sculpins of the Cottus carolinae species group in Perry County, Missouri: distribution, external morphology, and conservation status review. Env. Biol. Fish. 62: 279-296 (this volume).

Cardona, L. \& G. Guerao. 1994. Astroblepus riberae, una nueva especie de siluriforme cavernícola del Peru (Osteichthyes: Astroblepidae). Mém. Biospéléol. (21): 21-24.

Carranza, J. 1954. Descripcion del primer bagre anoftalmo y depigmentado encontrado en aguas mexicanas (Pisc., Ameiur.) Ciencia (Mexico) 14: 129-136.

Carvalho, A.M. \& M.C.C. de Pinna. 1986. Estudo de uma populacao hipogea de Trichomycterus (Ostariophysi, Siluroidei, Trichomucteridae) da Gruta de Olhos d'Agua, MG. Espeleo-Tema 15: 53-64.

Chardon, M. 1966. Specialisation anatomique de l'appareil de Weber d'Astroblepus pholeter, silure cavernicole microphtalme de la Republique de l'Equateur. Acad. Roy. Belg. Bull. Cl. Sci. 52: 846-863.

Chen, Y.-Y., X.-L. Chu, Z.-Y. Luo \& J.-Y. Wu. 1988. A new blind cyprinid fish from Yunnan, China with a reference to the evolution of its characters. Acta Zool. Sin. 34: 64-70 (in Chinese).

Chen, Y.-R., J.-X. Yang \& J.-H. Lan. 1997. One new specie of blind cavefish from Guangxi with comments on its phy logenetic status (Cypriniformes: Cyprinidae: Barbinae). Acta Zootaxon. Sin. 22: 219-223 (in Chinese).

Chen, Y.-R., J.-X. Yang, B. Sket \& G. Aljancic. 1998. A new blind cave loach of Paracobitis with comments on its characters evolution. Zool. Res. 19: 59-63 (in Chinese).

Chen, Y.-R., J.-X. Yang \& G.-C. Xu. 1992. A new blind loach of Triplophysa from Yunnan Stone Forest with comments on its phylogenetic reiationship [sic]. Zool. Res. 13:17-23 (in Chinese).

Chen, Y.-R., J.-X. Yang \& Z-G. Zhu. 1994. A new fish of the genus Sinocyclocheilus from Yunnan with comments on its characteristic adaptation (Cypriniformes: Cyprinidae). Acta Zool. Sin. 19: 246-253 (in Chinese)

Chu, S.-L. \& Y.-R. Chen. 1979. A new blind cobitid fish (Pisces, Cypriniformes) from subterranean waters in Yunnan, China Acta Zool. Sin. 25: 285-287 (in Chinese).

Chu, X.-L. \& Y.-R. Chen. 1982. A new genus and species of blind cyprinid fish from China with special reference to it relationships. Acta Zool. Sin. 28: 383-388 (in Chinese).

Chumba-Segura, L. 1983. Brotulidae: Typhliasina pearsei. Fauna de Los Cenotes de Yucatan (4): 1-9.

Chumba-Segura, L. 1984. Synbranchidae: Ophisternon infernale. Fauna de Los Cenotes de Yucatán (6): 1-9.

Coad, B.W. 1996. Threatened fishes of the world: Iranocypris typhlops Bruun \& Kaiser, 1944 (Cyprinidac). Env. Biol. Fish. 46. 374
Collette, B.B. 1962. Astroblepus pholeter, a new species of cavedwelling catfish from eastern Ecuador. Proc. Biol. Soc. Wash. 75: 311-314

Cohen, D.M. \& C.R. Robins. 1970. A new ophidioid fish (genus Lucifuga) from a limestone sink, New Providence Island, Bahamas. Proc. Biol. Soc. Wash. 83: 133-144.

Contreras-Balderas, S. \& M. de L. Lozano-Vilano. 1988. Problemas nomenclaturales de las formas mexicanas del géner Astyanax (Pisces:Characidae). Zoología Informa (38): 1-13.

Cooper, J.E. \& R.A. Kuehne. 1974. Speoplatyrhinus poulsoni, a new genus and species of subterranean fish from Alabama. Copeia 1974: 486-493.

Cuvier, G. 1819. Sur les poissons du sous-genre Hydrocyon, sur deux nouvelles espèces de Chalceus, sur trois nouvelles espèces du serrasalmes, et sur l'Argentina glossodonta de Forskahl, qu est l'Albula gonorhynchus de Bloch. Mem. Mus. Natl. Hist Nat. 5: 351-379.

Dai, D.-Y. 1988. Un nouveau poisson cavernicole. Spelunca Mem. (16): 88-89.

Day, F. 1872. Monograph of Indian Cyprinidae, Part IV. J. Asiatic Soc. 41: 171-198.

DeKay, J.E. 1842. Zoology of New York or the New-York fauna, Part IV, fishes. W. \& A. White \& J. Visscher, Albany. 566 pp.

De Filippi, F. 1853. Nouvelles espèces de poissons. Rev. Mag. Zool. (Ser. 2) v. 5 ; $164-171$.

de Pinna, M.C.C. 1998. Phylogenetic relationships of neotropi cal Siluriformes (Teleostei: Ostariophysi): historical overview and synthesis of hypotheses. pp. 279-330. In: L.R. Malabarba, R.E. Reis, R.P. Vari, Z.M. Lucena \& C.A.S. Lucena (ed.) Phylogeny and Classification of Neotropical Fishes, Edipucrs, Porto Alegre.

Díaz Perez, P.A. 1988. Lucifuga teresinarum sp. n., nueva especie cubana de peces troglobios (Ophidiiformes, Bythitidä). Rev. Biol. (Habana) 2: 37-43.

Di Caporiacco, L. 1926. Un nuovo genere di ciprinide somalo delle acque di pozzo (One new cyprinid genus from a well in Somalia). Monit. Zool. Ital. 37: 23-25.

Di Capporiacco, L. 1927. Pesci recolti in Somalia nel 1924, della spedizione Stefanini e Puccini. Monit. Zool. Ital. 38: 84-89.

Durand, J. 1968. Etude des poissons récoltés dans la grotte de Umayalanta (Bolivie), Trichomycterus chaberti sp. $\mathrm{n}$. Ann. Spéléol. 23: 343-353.

Eapen, K.C. 1963. A new species of Monoptereus from South India. Bull. Dept. Mar. Biol. Ocean. Univ, Kerala 1: 129-132.

Eigenmann, C.H. 1897. The Amblyopsidae and eyes of blind fishes. Proc. Indiana Acad. Sci. 1897: 230-231.

Eigenmann, C.H. 1898. On the Amblyopsidae. Science 7: 227.

Eigenmann, C.H. 1899. A case of convergence. Proc. Indiana Acad. Sci. 1899: 247-251.

Eigenmann, C.H. 1905. Divergence and convergence in fishes Biol. Bull. Woods Hole 8: 59-66.

Eigenmann, C.H. 1912. The freshwater fishes of British Guiana, including a study of the ecological grouping of species, and the relation of the fauna of the plateau to that of the lowlands. Mem. Carnegie Mus. 5: 1-103.

Eigenmann, C.H. 1919. Trogloglanis pattersoni a new blind fish from San Antonio, Texas. Proc. Am. Philos. Soc. 58: 397-400. 
Erckens, W. \& F. Weber. 1976. Rudiments of an ability for time measuremens in cavernicole fish Anoptichthys jor dani Hubbs \& Innes (Pisces: Characidae). Experientia 32 1297-1299.

Ercolini, A. \& R. Berti. 1975. Light sensitivity experiments and morphology studies of the blind phreatic fish Phreatichthys andruzzii Vinciguerra from Somalia. Monit. Zool. Ital. 6 : $29-43$.

Ercolini, A. \& R. Berti. 1977. Morphology and response to light of Uegitglanis zammaranoi Gianferrari, anophthalmic phreatic fish from Somalia. Monit. Zool. Ital. 9: 183-199.

Ercolini, A. \& R. Berti. 1978. Morphology and response to light of Barbopsis devecchii di Caporiacco (Cyprinidae), microphthalmic phreatic fish from Somalia. Monit. Zool. Ital. 10: 299-314.

Ercolini, A., R. Berti, L. Chelazzi \& G. Messana. 1982 Researches on the phreatobic fishes of Somalia: achievements and prospects. Monit. Zool. Ital. 17: 219-241.

Ercolini, A., R. Berti, L. Chelazzi \& G. Messana. 1987. Oxygen consumption in hypogean and epigean cyprinids (Pisces) Monit. Zool. Ital. 22(Suppl.): 23-30.

Espinasa, L., P. Rivas-Manzano \& H. Espinosa Pérez. 2001. A new blind cave fish population of genus Astyanax: geography, morphology and behavior. Env. Biol. Fish. 62: 339-344 (this volume).

Etnier, D.A. \& W.C. Starnes. 1993. The fishes of Tennessee. University of Tennessee Press, Knoxville. 681 pp.

Fowler, H.W. \& H. Steinitz. 1956. Fishes from Cyprus, Iran, Iraq Israel and Oman. Bull. Res. Counc. Israel. 5B: 260-292.

Galán, C. 1982. Fauna troglobia de Venezuela: sinopsis, biología, ambiente, distribución y evolución. Bol. Soc. Venez. Speleol. (29): 20-38.

Galán, C. 1995. Fauna troglobia de Venezuela: sinopsis, biología, ambiente, distribución y evolución. Bol. Soc. Venez. Speleol. 29: 20-38.

Gerard, P. 1936. Sur l'existence des vestiges oculaires chez Cae cobarbus geertsi. Mus. Roy. Hist. Nat. Melages P. Pelseneer 1936: 549-552.

Géry, J. 1977. Characoids of the world. T.F.H. Publications, Neptune City. 672 pp.

Gianferrari, L. 1923. Uegitglanis zammaranoi un nuovo siluride cieco africano (Uegitglanis zammaranoi, a new African cave silurid). Soc. Ital. Sci. Nat. Milan. 62: 1-3.

Gianferrari, L. 1930. Un nuovo ciprinide Somalo (Barbopsis Stefaninii Gianf.). Atti. Soc. Ital. Sci. Nat. (Milano) 69: 106-111.

Gianferrari, L. 1934. I pesci cavernicoli ciechi africani. Ross. Fauna 2: 33-36.

Girard, C.F. 1859. Ichthyological notes. Proc. Acad. Nat. Sci. Phila. 1859: 63-64.

Goeldi, E.A. 1905. Nova zoologica aus der Amazonas-Region. Nene Wirbelticre. C.R. 6. Congr. Internat. Zool., Berne 1905: 542-549.

Gordon, M.S. \& G.E. Rosen. 1962. A cavernicolous form of the poeciliid fish Poecilia sphenops from Tabasco, Mexico. Copeia 1962: 360-368.

Gotch, A.F. 1995. Latin names explained. A guide to the scientific classification of reptiles, birds \& mammals. Facts on File, New York. 714 pp.
Green, S. \& A. Romero. 1997. Responses to light in two blind cave fishes (Amblyopsis spelaea and Typhlichthys subterraneus) (Pisces: Amblyopsidae). Env. Biol. Fish. 50: 167-174.

Greenfield, D.W., T.A. Greenfield \& R.L. Woods. 1982. A new subspecies of cave-dwelling pimelodid catfish, Rhamdia laticauda typhla from Belize, Central America. Brenesia (19/20): 563-576.

Greenwood, P.H. 1976. A new and eyeless cobitid fish (Pisces, Cypriniformes) from the Zagros Mountains, Iran. J. Zool. 180 129-137.

Haseman, J.D. 1911. Descriptions of some new species of fishes and miscellaneous notes on others obtained during the expedition of the Carnegic Museum to central South America. Ann. Carnegie Mus. 7: 315-328.

Hendrickson, D.A., J.K. Krejca \& J.M. Rodríquez Martinez. 2001. Mexican blindcats genus Prietella (Siluriformes: Ictaluridae): an overview of recent explorations. Env. Biol. Fish. 62: 315-337 (this volume).

Heuts, M.-J. 1951. Ecology, variation and adaptation of the blind African cave fish Caecobarbus geerstsii Blgr. Ann. Soc. Roy. Zool. Belg. 82: 115-230.

Heuts, M.J. \& N. Leleup. 1954. La geographie et l'ecologie des grottes du Bas-Congoles habitats de Caecobarbus geertsi Blgr. Ann. Mus. Roy. Congo Belge 35: 1-71.

Hora, S.L. 1924. Fish of the Siju Cave, Garo Hills, Assam. Rec. Indian Mus. 26: 27-31.

Hubbs, C.L. 1936. XVII. Fishes of the Yucatan Peninsula. Carnegie Inst. Wash. Publ. (457): 157-287.

Hubbs, C.L. 1938. Fishes from the caves of Yucatan. Carnegic Inst. Wash. Publ (491): 261-295.

Hubbs, C.L. 1961. Isolating mechanisms in the speciation of fishes. pp. 5-23. In: W.F. Blair (ed.) Vertebrate Speciation: A symposium, University of Texas Press, Austin. .

Hubbs, C.L. \& R.M. Bailey. 1947. Blind catfishes from artesian waters of Texas. Occas. Pap. Mus. Zool. Univ. Mich. (499): $1-15$

Hubbs, C.L. \& W.T. Innes. 1936. The first known blind fish of the family Characidac: a new genus from Mexico. Occas. Pap. Mus. Zool. Univ. Mich. (342): 1-7.

Humboldt, A. von. 1805. Mémoire sur une nouvelle espèce de pimelode, jetée par les volcans du Royaume de Quito. Voyage de Humboldt et Bonpland, Deuxième partie, Observations de Zoologie et d'Anatomie comparéc, Paris 1: 21-25.

Humphreys, W.F. 1999. The distribution of Australian cave fishes Rec. Western Austr. Mus. 19: 469-472.

Humphreys, W.F. 2001. Milyeringa veritas (Eleotridae), a remarkably versatile cave fish from the arid tropics of northwestern Australia. Env. Biol. Fish. 62: 297-313 (this volume).

Humphreys, W.F. \& M.N. Feinberg. 1995. Food of the blind cave fishes of northwestern Australia. Rec. Western. Austr. Mus. 17 $29-33$.

Iliffe, T.M. 1991. Archialine fauna of the Galapagos islands. pp. 209-231. In: M.J. James (ed.) Galapagos Marine Invertebrates, Plenum Press, New York.

Iliffe, T.M. 1992. Anchialine cave biology. pp. 613-636. In: A.I. Camacho (ed.) The Natural History of Biospeleology, Museo Nacional de Ciencias Naturales, Madrid.

Jaeger, F. \& L. Waibel. 1921. Beiträge zur Landeskunde von Südwestafrika. E.S. Mittler, Berlin. 80 pp. 
Jankowska, M. \& G. Thinès. 1982. A comparative study of group density in cave and epigean fishes. Behav. Proc. 7: 281-294.

Kirby, R.F., K.W. Thompson \& C. Hubbs. 1977. Karyotypic similarities between the Mexican and blind tetras. Copeia 1977: 578-580.

Kottelat, M. 1988. Two species of cavefishes from northern Thailand in the genera Nemacheilus and Homaloptera (Osteichthyes: Homalopteridae). Rec. Aust. Mus. 40: 225-231.

Kottelat, M. 1990. New species and populations of cave nemacheilines in south and south-east Asia (Osteichthyes, Balitoridae). Mém. Biospéleol. 17: 49-55.

Kottelat, M. 1998. Homaloptera yuwonoi, a new species of hillstream loach from Borneo, with a new generic name for H. thamicola (Teleostei, Balitoridae). Ichthy. Expl. Freshw. 9: 267-272.

Kottelat M. \& F. Bréhier. 1999. Troglocyclocheilus khammouanensis, a new genus and species of cave fish from the Khammouan karst, Laos (Teleostei, Cyprinidae). Rev. Suiss. Zool. 106: 347-359.

Kottelat, M. \& J. Géry. 1989. Nemacheilus troglocataractus, a new blind cavefish from Thailand. (Osteichthyes, Balitoridac). Spixiana 11: 273-277.

Li, G.-L. 1989. On a new fish of the genus Sincyclocheilus from Guangxi, China (Cypriniformes: Cyprinidae: Barbinae). Acta Zootaxon. Sin. 14: 123-126 (in Chinese).

Lin, R.-D. \& Z.-F. Luo. 1986. A new blind barbid fish (Pisces, Cyprinidae) from subterranean water in Guangxi, China. Acta Hydrobiol. Sin. 10: 380-382 (in Chinese).

Longley, G. \& H. Karnei. 1979. Status of Trogloglanis pattersoni Eigenmann, the toothless blindcat and status of Satan eurystomus Hubbs and Bailey, the widemouth blindcat. U.S. Fish and Wildlife Service, Albuquerque. $54 \mathrm{pp}$.

Lozano-Vilano, M. de L. \& S. Contreras-Balderas. 1990. Astyanax armandoi, n. sp. from Chiapas, mexico (Pisces, Ostariophysi: Characidae) with a comparison to the nominal species A. aeneus and A. mexicanus. Universidad Y Ciencia 7 95-107.

Mai, D.Y. 1978. Identification of the fresh-water fishes of North Viet Nam. Scientific \& Technology Publisher, Hanoi. 340 pp. (in Vietnamese).

Marshall, N.B. \& G.L. Thines. 1958. Studies of the brain, sense organs and light sensitivity of a blind cave fish (Tvphlogarra widdow:soni) from Iraq. Proc. Zool. Soc. London 131: 441-456.

Masuda, H., K. Amaoka, C. Araga, T. Uyeno \& T. Yoshino 1984 The fishes of the Japanese Archipelago. Tokai University Press, Tokyo. 437 pp.

Mees, G.F. 1962. The subterranean freshwater fauna of Yardie Creek Station, North West Cape, Western Australia. J. R. Soc. West. Aust. 45: 24-32

Menon, A.G.K. 1950. On a remarkable blind siluroid fish of the family Clariidae from Kerala (India). Rec. Indian Mus. 48: $59-66$

Menon, A.G.K. 1987. The fauna of India and the adjacent countries. Amra Press, Madras. 259 pp.

Mercy, T.V.A., K.G. Padmanabhan \& N.K. Pillai. 1982. Morphological studies on the oocytes of the blind catfish Horaglanis krishnai Menon. Zool. Anz. 209: 221-223.

Mercy, T.V.A. \& N.K. Pillai. 1984-5. The anatomy and histology of the alimentary tract of the blind catfish Horaglanis krishnai. Int. J. Speleol. 14: 1-4.
Miller, R.R. 1984. Rhamdia reddelli, new species, the first blind pimelodid catfish from middle America, with a key to the Mexican species. Trans. San Diego Soc. Nat. Hist. 20: 135-144.

Miranda-Ribeiro, A. de 1907. Uma novidade ichthyologica. Kosmos 4: 1-3.

Mitchell, R.W., W.H. Russel \& W.R. Elliot. 1977. Mexican eyeless characin fishes, genus Astyanax: environment, distribution, and evolution. Special Publications No. 12, Texas University Press, Lubbock. 89 pp.

Nalbant, T.T. 1981. A study of the subterranean species of Lucifuga from Cuba, with the description of Lucifuga simile sp. n. (Pisces, Ophidiiformes, Bythitidae). Résult. Expéd. Biospéol. Cubano-Roum. Cuba 3: 185-190.

Nalbant, T.T. \& P.G. Bianco. 1998. The loaches of Iran and adjacent regions with description of six new species (Cobitoidea). Ital. J. Zool. 65: 109-123.

Nalbant, T.T. \& O. Linares. 1987. A study of a subterranean population of Trichomycterus guianense (Eigenmann, 1909) from Venezuela (Pisces, Siluriformes, Trichomycteridae). pp. 211-218. In: V. Decu (ed.) Fauna Hipogea y Hemiedáfica de Venezuela y de Otros Paises de América del Sur, Editura Academiei Republicii Sociliste Romania, Bucarești.

Nelson, J.S. 1994. Fishes of the world. John Wiley \& Sons, New York. 600 pp.

Ng, H.H. \& M. Kottelat.1998. Pterocryptis buccata, a new species of catfish from western Thailand (Teleostei: Siluridae) with epigean and hypogean populations. Ichth. Research 45: 393-399.

Nielsen, J.G. 1974. Fish types in the Zoological Museum of Copenhagen. Zoological Museum, University of Copenhagen, Copenhagen. $115 \mathrm{pp}$.

Norman, J.R. 1926. A new blind catfish from Trinidad, with a list of the blind cave-fishes. Ann. Mag. Nat. Hist. 18: 324-331.

Page, L.M. \& B.M. Burr. 1991. A field guide to freshwater fishes, North America, north of Mexico. The Peterson Field Guide Series, Boston. 432 pp.

Parin, N.V. 1983. Noemacheilus (Troglocobitis) starostini sp. n. (Osteichthyes, Cobitidae) a new blind fish from subterranean waters of Kugitangtau (Turkmenia). Zool. Zh. 62: 83-89 (in Russian).

Parzefal, J. 2001. A review of morphological and behavioural changes in the cave molly, Poecilia mexicana, from Tabasco, Mexico. Env. Biol. Fish. 62: 263-275 (this volume).

Pellegrin, J. 1929. L'Eilichthys microphthalmus Pellegrin, poisson cavernicole de la Somalie Italienne. Bull. Mus. Hist. Nat. Paris 1: 363-364.

Pérez, J.E. \& G.E.E. Moodie. 1993. Genetic variation in a cave-dwelling Venezuelan catfish. Acta Cient. Venez. 44 $28-31$.

Pérez, A. \& A. Viloria.1994. Ancistrus galani n. sp. (Siluriformes: Loricariidae), with comments on biospeleological explorations in western Venezuela. Mém. Biospéléol. 21: 103-107.

Peters, N. \& G. Peters. 1973. Problemes genetiques de l'evolution regressive des cavernicoles. pp. 187-201. In: L.H. Schroeder (ed.) Genetics and Mutagenesis in Fish, Springer-Verlag, New York.

Petit, G. 1933. Un poisson cavernicole aveugle des eaux douces de Madagascar: Typhleotris madagascariensis gen. et sp, nov. C.R. Hebd. Seances Acad. Sci. 197: 347-348. 
Pfeiffer, W. 1966. Über die Vererbung des Schreckreaktion bei Astyanax (Characidae, Pisces). Z. Vererbungel. 98: 97-105.

Pillai, R.S. \& G.M. Yazdani. 1977. Ichthyo-fauna of Garo Hills, Meghalaya (India). Rec. Zool. Surv. India 72: 1-22.

Poey, F. 1858. Memorias sobre la historia natural de la isla de Cuba, 2 volumes. Barcina, Habana. 439 pp.

Poisson, H. \& H. Bessairie. 1947. Note sur une novelle station d'un poisson cavernicole aveugle du plateau calcaire Mahafaly. Bull. Acad. Malgache 26: 167-168.

Poll, M. \& N. LeLeup. 1965. Un poisson aveugle nouveau de la famille des Brotulidae provenant des îles Galapagos. Bull. Acad. R. Belg. (Cl. Sci.) 51: 464474

Poly, W.J. 200I. Nontroglobitic fishes in Bruffey-Hills Creek Cave, West Virginia, and other caves worldwide. Env. Biol. Fish. 62: 73-83 (this volume).

Poulson, T.L. 1963. Cave adaptation in amblyopsid fishes. Amer. Midl. Nat. 70: 257-290.

Proudlove, G.S. 2001. The conservation status of hypogean fishes. Env. Biol. Fish. 62: 201-203 (this volume).

Putnam, F.W. 1872. The blind fishes of the Mammoth Cave and their allies. Amer. Nat. 6: 6-30.

Quoy, J.R.C. \& J.P. Gaimard 1824. Description des poissons. pp. 1-328. In: L. De Freycinet (ed.) Voyage autour du Monde...exécuté sur les corvettes de L.M. 'L'Uranie' et 'La Physicienne,' pendant les années 1817, 1818, 1819 et 1820. Chez Pillet Aîné, Paris ( 7 volumes)

Regan, C.T. 1913. A revision of the cyprinodont fishes of the subfamily Poeciliinae. Proc. Zool. Soc. Lond. 1913:977-1018.

Regan, C.T. 1940. The fishes of the gobiid genus Luciogobius Gill. Ann. Mag. Nat. Hist. 5: 462-465.

Reis, R.E. 1987. Ancistrus cryptophthalmus sp. n., a blind mailed catfish from the Tocantins River basin, Brazil (Pisces, Siluriformes, Loricariidae). Rev. Fr. Aquariol. 14: 81-84.

Ringuelet, R.A. 1974. Breves comentarios sobre un pez cavernicola de Bolivia (Pygidium chaberti Durand, 1968). Neotropica 20: 65-66.

Roberts, T.R. 1991. Barbus speleops new species, a blind cavefish from Tham Phu Khieo, Mekong Basin, Thailand. Nat. Hist. Bull. Siam Soc. 39: 103-109.

Romero, A. 1983. Introgressive hybridization in a population of Astyanax fasciatus (Pisces: Characidae) at La Cueva Chica. Nat. Speleol. Soc. Bull. 45: 81-85.

Romero, A. 1984. Behavior in an 'intermediate' population of the subterranean-dwelling characid Astyanax fasciatus. Env. Biol. Fish. 10: 203-207.

Romero, A. 1985. Ontogenetic change in phototactic responses of surface and cave populations of Astyanax fasciatus (Pisces: Characidae). Copeia 1985: 1004-1011.

Romero, A. 1987. Observaciones preliminares sobre la conducta en individuos cavernícolas de Trichomycterus conradi (Pisces: Trichomycteridae). Bol. Soc. Ven. Cienc. Nat. 41: 205-216.

Romero, A. 1998a. Threatened fishes of the world: Amblyopsis rosae (Eigenmann, 1842) (Amblyopsidae). Env. Biol. Fish. 52: 434.

Romero, A. 1998b. Threatened fishes of the world: Typhlichthys subterraneus (Girard, 1860) (Amblyopsidae). Env. Biol. Fish. 53: 74 .

Romero, A. 1998c. Threatened fishes of the world: Speoplatyrhinus poulsoni Cooper and Kuehne, 1974 (Amblyopsidae). Env. Biol. Fish. 53: 293-294.
Romero, A. 2001. Scientists prefer them blind: the history of hypogean fish research. Env. Biol. Fish. 62: 43-71 (this volume).

Romero, A. \& L. Bennis. 1998. Threatened fishes of the world: Amblyopsis spelaea De Kay, 1842 (Amblyopsidae). Env. Biol. Fish. 51: 420 .

Romero, A. \& K. Benz. 2000. The unsung heroes of speleology. Nat. Speleol. Soc. News 58: 106, 126

Romero, A. \& J.E. Creswell. 2000. In search of the elusive 'eyeless' cave fish Trinidad, W.I. Nat. Speleol. Soc. News 58 : $282-283$.

Romero, A. \& A. McLeran. 2000. Threatened fishes of the world: Stygichthys typhlops Brittan \& Böhlke, 1965 (Characidae). Env. Biol. Fish. 57: 270

Romero, A. \& K.M. Paulson. 2001. Humboldt's alleged cave fish from Ecuador. J. Spelean Hist. (in press).

Romero, A. \& P.B.S. Vanselow, 2000a. Threatened fishes of the world: Milyeringa veritas Whitley, 1945 (Eleotridae). Env. Biol. Fish. 57: 36.

Romero, A. \& P.B.S. Vanselow. 2000b. Threatened fishes of the world: Ophisternon candidum (Mees 1962) (Synbranchidae). Env. Biol. Fish. 58: 214

Sabino, J. \& E. Trajano. 1997. A new species of blind armoured catfish, genus Ancistrus, from caves of Bodoquena region, Mato Grosso do Sul, southwestern Brazil (Siluriformes, Loricariidae, Ancistrinae). Rev. Fr. Aquariol. 24: 73-78.

Sadoglu, P. 1957. Mendelian inheritance in the hybrids between the Mexican blind cave fishes and their overground ancestor. Verh. Dtsch. Zool. Ges., Graz 1957: 432-439.

Sbordoni, M.C., E. De Matthaeis, M. Mattoccia, R. Berti \& V. Sbordoni. 1996. Genetic variability and differentiation of hypogean cyprinid fishes from Somalia. J. Zool. Syst. Evol. Res. 34: 75-84.

Schemmel, C. 1967. Vergleichende Untersuchungen an den Hautsinnesorganen ober-und unterirdisch Lebender AstyanaxFormen, ein Beitrag zur evolution der Cavernicolen. Z. Morph. Tiere 61: 255-316.

Schemmel, C. 1980. Studies on the genetics of feeding behaviour in the cave fish Astyanax mexicanus f. Anoptichthys. An example of apparent monofactorial inheritance by polygenes. Z. Tierpsychol. 53: 9-22.

Schultz, L.P. 1949. A further contribution to the ichthyology of Venezuela. Proc. U.S. Nat. Mus. 99: 1-211.

Silas, E.G. \& E. Dawson. 1961. Amphipnous indicus, a new synbranchoid eel from India, with a redefinition of the genus and a synopsis to the species of Amphipnous Müller. J. Bombay Nat. Hist. Soc. 58: 366-378.

Silfvergrip, A.M.C. 1996. A systematic revision of the neotropical catfish genus Rhamdia (Teleostei, Pimelodidae). Swedish Museum of Natural History, Stockholm. 156 pp.

Singh, D.F. \& G.M. Yazdani. 1993. Studies on the ichthyofauna of Nasik District, Maharashtra, India. Rec. Zool. Surv. India 90: 195-201.

Sket, B. 1988. Speleobiological investigations in the Colombian Andes. Vest. Leningr. Univ. Ser. 3, Biol. 36: 53-62.

Smirnov, S. 1983. A blind cave loach from southwestern Asia, Noemacheilus starostini Parin. Trop. Fish Hobb. (3): 54-58. Steindachner, F. 1863. Beiträge zur Kenntniss der Sciaenoiden Brasiliens und der Cyprinodonten Mejicos. Sitzungsber. Math.Naturwiss., Classe K. Akad. Wiss., Wien 48: 162-185. 
Talwar, P.K. \& A.G. Jhingran. 1991. Inland fishes of India and adjacent countries. Oxford \& IBH Publishing Co., Calcutta. 2 volumes, $1158 \mathrm{pp}$.

Thinès, G. 1953. Recherches experimentales sur la photosensibilité du poisson aveugle Caecobarbus geertsii Blgr. Ann. Soc. Roy. Zool. Belg. 84: 231-265.

Thinès, G. 1969. L'évolution régressive des poissons cavernicoles et abyssaux. Masson et Cie., Paris. 394 pp.

Thinès, G. \& J.-M. Legrain. 1973. Effects de la substance d'alarme sur le comportament des poissons cavernicoles Anoptichthys jordani (Characidae) et Caecobarbus geeretsi (Cyprinidae). Ann. Speleol. 28: 291-297.

Tomiyama, I. 1936. Gobiidae of Japan. Japan. J. Zool. 7: 37-112.

Torii, H. 1951. Die Hohleen-Vertebraten aus Japan und seinen Nachbarschaften. Annot. Zool. Japan. 24: 170-179.

Trajano, E. 1991. The agonistic behaviour of Pimelodella kronei, a troglobitic catfish from southeastern Brazil (Siluriformes, Pimelodidade). Behav. Proc. 23: 113-124.

Trajano, E. 1997a. Food and reproduction of Trichomycterus itacarambiensis, cave catfish from south-eastern Brazil. J. Fish Biol. 51: 53-63.

Trajano, E. 1997b. Population ecology of Trichomycterus itacarambiensis, a cave catfish from eastern Brazil (Siluriformes, Trichomycteridae). Env. Biol. Fish. 50: 357-369.

Trajano, E. 1997c. Synopsis of Brazilian troglomorphic fishes. Mem. Biospeleol. 24: 119-126.

Trajano, E. 200la. Ecology of subterranean fishes: an overview. Env. Biol. Fish. 62: 133-160 (this volume)

Trajano, E. 2001b. Habitat and population data of troglobitic armoured cave catfishes, Ancistrus cryptophthalmus Reis, 1987, from central Brazil (Siluriformes: Loricariidae). Eny. Biol. Fish. 62: 195-200 (this volume).

Trajano, E. \& M.C.C. de Pinna. 1996. A new cave species of Trichomycterus from eastern Brazil (Siluriformes, Trichomycteridae). Rev. Fr. Aquariol. 23: 85-90.

Trajano, E. \& A.M. Souza. 1994. The behavior of Ancistrus cryptophthalmus, an armoured blind catfish from caves of central Brazil, with notes on synopic Trichomycterus sp. (Siluriformes, Loricariidae, Trichomycteridae). Mém. Biospeléol. 21: 151-159.

Trewavas, E. 1936. Dr. Karl Jordan's expedition to South-West Africa and Angola: the fresh-water fishes. Novit. Zool. 40: 63-74.

Trewavas, E. 1955. A blind fish from Iraq, related to Garra. Ann. Mag. Nat. Hist. 8: 551-555,

Triques, M.L. 1996. Eigenmannia vicentespelaea, a new species of cave dwelling electrogenic neotropical fish (Ostariophisi: Gymnotiformes: Sternopygidac). Rev. Fr. Aquariol. 23: 1-4.

Uéno, S.-I. \& Y. Morimoto. 1970. The fauna of the insular lava caves in west Japan. I. General account. Bull. Nat. Sci. Mus (Japan) 13: 443-454

Valenciennes, A.in G. Cuvier \& A. Valenciennes, 1846. Histoire naturelle des poissons, Tome dix-huitième. Suite du livre dix-huitième, Cyprinö̈des. Livre dix-neuvième, Des Ésoces ou Lucioïdes 18: 1-505.
Vinciguerra, D. 1924. Descrizione di un ciprinide cieco proveniente dalla Somalia Italiana (Description of a blind cyprinid from the Italian Somalia). Ann. Mus. Civ. Stor. Nat. Genoa 51 : 239-243.

Walsh, S.J. \& C.R. Gilbert. 1995. New species of troglobitic catfish of the genus Prietella (Siluriformes: Ictaluridae) from northeastern México. Copeia 1995: 850-861.

Weber, A. 2000. Fish and amphibia. pp. 109-132. In: H. Wilkens, D.C. Culver \& W.F. Humphrey (ed.) Subterranean Ecosystems, Elsevier, Amsterdam.

Weber, A. \& H. Wilkens, 1998. Rhamdia macuspanensis: new species of troglobitic pimelodid catfish (Siluriformes; Pimelodidae) from a cave in Tabasco, Mexico. Copeia 1998: 998-1004.

Whitley, G.P. 1945. New sharks and fishes from Western Australia, Part 2. Aust. Zool. 11: 1-42.

Whitley, G.P. 1951 a. A naturalist at north-west Cape. Austr. Mus Mag. 5: $158-164$.

Whitley, G.P. 1951b. New fish names and records. Proc. R. Zool. Soc. N. S. W. 1949-50: 61-68.

Wilkens, H. 1969. Beitrage zur Degeneration des Auges be Cavernicolen, Genzahl und Manifestationsart. Zool. Anz. 180: 454-464.

Wilkens, H. 1973. Über das phylogenetische Alter von Hohlentieren. Untersuchungen über die Cavernicole Susswasserfauna Yucatans. Sond. Z. Zool. Syst. Evol. 11: 49-60.

Wilkens, H. 1993. A new species of Rhamdia (Pisces: Pimelodidae) from a cave in the Sicra de Zongolica (Veracruz, Mexico). Mitt. Hamb. Zool. Mus. Inst. 90: 375-378.

Wilson, J.M. 1996. Conservation and ecology of a new blind fish Glossogobius ankaranensis from the Ankarana caves, Masagascar. Oryx: 30: 218-221.

Yang, J.-X. 1990. Nemacheilinae (Cypriniformes: Cobitidae). pp. 12-63. In: X. Chu \& Y. Chen (ed.) The Fishes of Yunnan, China, Part 2. Science Press, Beijing (in Chinese).

Yang, J.-X., Y.-R. Chen \& J.-H. Lan. 1994. Protocobitis typhlops, a new genus and species of cave loach from China (Cypriniformes: Cobitidae). Ichthyol. Explor. Freshwaters 5: 91-96.

Yang, G.-Y., F.-X. Yuan \& Y.-M. Liao. 1986. A new blind Cobitidae fish from the subterranean water in Xiangxi, China. J. Huazhong Agric. Univ. 5: 219-223 (in Chinese).

Zhang. C. 1986. On the ecological adaptation and geographical distribution of the barbine fish Varicorhinus (Scaphestes) macrolepis. Acta Zool. Sin. 32: 266-272.

Zheng, J. \& J. Wang. 1990. Description of a new species of the genus Sinocyclocheilus from China (Cypriniformes: Cyprinidae). Acta Zootaxon. Sin. 15: 251-254 (in Chinese).

Zhou, W. \& G.-H. Cui. 1997. Fishes of the genus Triplophysa (Cypriniformes: Balitoridae) in the Yuanjiang (upper Red River) basin of Yunnan, China, with description of a new species. Ichthyol. Explor. Freshw. 8: 177-183.

Zhu, S.-Q. 1989. The loaches of the subfamily Nemacheilinae in China (Cypriniformes: Cobitidae). Jiangsu Science and Technology Publishing House, Nanjing. 150 pp. (in Chinese). 